\title{
Pensononowoor
}

2019, vol. 82, 24-42

http://dx.doi.org/10.12657/denbio.082.004

\author{
Stanislav Vacek, Zdeněk Vacek, Lukáš Bílek*, Jiří Remeš, \\ Iva Hůnová, Daniel Bulušek, Jan Král, Jakub Brichta
}

\section{Stand dynamics in natural Scots pine forests as a model for adaptation management?}

Received: 16 August 2019; Accepted: 16 December 2019

\begin{abstract}
The paper deals with the dynamics of structure, diversity and growth of natural pine stands without direct human impact during the ten-year period in Nature Reserve (NR) Kostelecké bory, Czech Republic. The objective was to determine the main characteristics of the spontaneous development of Scots pine (Pinus sylvestris L.) forest stands in relation to their naturalness, ecological stability and adaptation to climate change and air pollution stress.

Horizontal and vertical structure and species diversity of the tree layer, dead wood and natural regeneration of each permanent research plot (PRP) were evaluated $(n=6,50 \times 50 \mathrm{~m} / 0.25 \mathrm{ha} /$, Northern Bohemia, 410-425 $\mathrm{m}$ above sea level). The average ring series of PRPs were correlated with the climatic data (precipitation, temperature) according to individual years from the Doksy climatic station, and the air pollution data $\left(\mathrm{SO}_{2}\right.$ in 1988-2015, $\mathrm{NO}_{\mathrm{x}}$ and AOT40F - ozone exposure in 1992-2015) from Radimovice station. In 2016, the stand volume increased by $26.0 \%$ to $136 \mathrm{~m}^{3} \mathrm{ha}^{-1}\left(108 \mathrm{~m}^{3} \mathrm{ha}^{-1}\right.$ in 2006) and the volume of dead wood increase by $127.2 \%$ to $27 \mathrm{~m}^{3} \mathrm{ha}^{-1}\left(12 \mathrm{~m}^{3} \mathrm{ha}^{-1}\right.$ in 2006). The horizontal structure of tree layer and natural regeneration was predominantly aggregated to random. More distinct changes in biodiversity and structural characteristics occurred in the natural regeneration $(21.5 \%)$ compared to tree layer $(2.8 \%)$. The precipitation had a significantly higher effect on radial growth compared to temperature. The lack of precipitation in growing season and high temperature in previous autumn and winter were limiting factors for growth. Climatic factors had significant effect on diameter increment in July of the current year $(\mathrm{P}<0.01)$ and June of the current and previous year $(\mathrm{P}<0.05)$. Radial growth was negatively correlated with $\mathrm{SO}_{2} \mathrm{con}_{-}$ centrations $(\mathrm{P}<0.01)$ and ozone exposure $(\mathrm{P}<0.05) . \mathrm{NO}_{\mathrm{X}}$ concentrations had low effect on radial growth. The natural stand dynamics had positive effect on biodiversity and functional integrity of natural pine ecosystems.
\end{abstract}

Keywords: Pinus sylvestris, forest dynamics, stands structure, air pollution, climatic factors, Central Europe

Addresses: S. Vacek, Z. Vacek, L. Bílek, J. Remeš, D. Bulušek, J. Král, J. Brichta, Czech University of Life Sciences Prague, Faculty of Forestry and Wood Sciences, Kamýcká 129, 16951 Prague 6 - Suchdol, Czech Republic, e-mail: bilek@fld.czu.cz

I. Hůnová, Czech Hydrometeorological Institute, Na Šabatce 2050/17, 14306 Prague 412-Komořany,

Czech Republic

*corresponding author 


\section{Introduction}

Autochthonous Scots pine (Pinus sylvestris L.) occurs in the Czech Republic in vegetation zones from the lowlands to the mountains. Its ecotypes are based on populations that survived the last glacial in various isolated refuges (Peřina, 1960). Contemporary autochthonous pine and pine-oak stands are the results of the vegetation development of predominantly the last 10,000 years in the postglacial period (Mikeska \& Vacek, 2008). These are azonal communities which gradually evolved from the preboreal and have been preserved only in extreme habitats with the limited competitiveness of other species (Matuszkiewicz et al., 2013). We naturally find these on a large scale in the Czech Republic only on poor and dry sandy soils. In other places, its natural appearance is bound to the relatively smaller extreme locations such as the rock outcrops and the edges of the crystalline and carbonate rocks and the sandstone rock towns (Kučera, 1999; Bohn et al., 2003; Vacek et al., 2017). Among the most important works characterizing these communities in Europe belong Passarge (1963), Lilja and Kuuluvainen (2005), Rouvinen and Kuuluvainen (2005), Gaudio et al. (2011), Matuszkiewicz et al. (2013).

Scots pine is considered to be an undemanding tree with pioneer strategy (Lanier et al., 1986; Zadworny et al., 2016). Apart from the mountain ecotypes, however, it is very demanding on light (De Chantal et al., 2003; Dehlin et al., 2004; Gaudio et al., 2011). At the same time, it is highly tolerant to drought (Picon-Cochard et al., 2006; Sanchez-Gomez et al., 2006). Many of its ecotypes are adapted to the entire range of habitats (Richardson, 2000; Medail, 2001; Ostonen, 2007; Sterck et al., 2012; Reich, 2014; Uria-Diez et al., 2017). Due to this, it is able to survive practically in any environment from waterlogged areas to xerothermic sites (Mikeska \& Vacek, 2008; Zadworny et al., 2017).

Pine as important commercial tree species has expanded significantly beyond its natural habitats in Europe in the last few centuries (Zerbe \& Brande, 2003; Mirschel et al., 2011). In addition to the increase of forest production, this change in species composition has led to a range of ecological problems, especially in monoculture stands (Kazda \& Pichler, 1998; Zaitsev et al., 2014). Recently, there is an evident trend to transform artificial forest into ecosystems with higher degree of naturalness (Zerbe, 2002; Schou et al., 2012; Hlásny et al., 2017) and higher resistance and resilience (Déchêne \& Buddle, 2010; Griess et al., 2012; Neuner et al., 2014; Allen et al., 2002; Reynolds et al., 2013; Salamon et al., 2008; Zaistev et al., 2014). In addition, in less productive pine forests, reduction in active management has occurred in recent decades, which may also result in positive successive changes (Vacek et al., 2017). Since 2006 the monitored stands and the whole Nature Reserve (NR) Kostelecké bory have been left to spontaneous development (Vacek et al., 2012). Practically, however, these stands have not been actively managed since the 1970s.

As such, the forests left to spontaneous development can be an important source of information for understanding natural processes and deriving procedures of close-to-nature silviculture (Burrascano et al., 2011; Petritan et al., 2014; Puettmann et al., 2015; Bílek et al., 2016). Understanding the forest development in response to natural disturbances and changing environmental conditions is very important for the setting of management approaches and measures (Pham et al., 2004; Dobrowolska \& Veblen, 2008; Durak \& Durak, 2015).

The aim of this paper is to evaluate the structure and development of selected stands of relict pine stands left to spontaneous development in the period from 2006 to 2016 . The structure of forest stands can be defined on the basis of a number of parameters (Spies \& Franklin, 1991; Poage \& Tappeiner, 2005). The structure includes both the vertical and the horizontal components and the species arrangement (Maltamo et al., 2005; Vacek et al., 2017). Since the relict pine stands left to spontaneous development have been scarcely explored from this point of view in Central Europe, we have focused on all the above-mentioned attributes in this paper. The basic scientific questions were as follows:

1. What are the main characteristics of the spontaneous development of natural pine forest under the given conditions?

2. Do these changes lead to higher naturalness and ecological stability of the studied stands?

3. Is the spontaneous development of pine stands on edaphically extreme sites a suitable adaptation measure to the ongoing climate change?

\section{Materials and Methods}

\section{Study Area}

The Kostelecké bory Nature Reserve, with an area of 51.2 hectares, was declared in 2003 and forms rock crests under the hill Kostelec ( $433 \mathrm{~m}$ above sea level). The geological bedrock is formed of the Mesozoic rectangular sandstone of the middle Turon. The most widespread soil type in the area is the arenic Podzol together with the arenic Cambisol on the sandstone slopes. The predominantly sandy soils are minerally poor and low in humus content. Climatically, the NR territory is classified according to Quitt (Quitt, 1971) as a slightly warm area MT9. The average annual temperature is approximately $7.5^{\circ} \mathrm{C}$ and 
the average annual rainfall is around $650 \mathrm{~mm}$ (Tolasz, 2007). The vegetation is formed by acidophilus forest communities. The Dicrano-Pinetum forest types (Pinetum relictum humile saxatile; Preising et Knapp ex Oberdorfer 1957) are bound to the ridges and rocky edges with a shallow layer of soil, and the cranberry pine-oak forests of Vaccinio vitis-idaeae-Quercetum roboris forest type (Oberdorfer 1957) are found marginally on the less exposed habitats. The tree layer of both communities is dominantly formed by pine (Chytrý et al., 2010; AOPK, 2014). The herb layer consists mainly of blueberry, cranberry, and several other acidophytes. Only in extreme locations in the pine stands, a more pronounced moss and lichen layer has developed. Among the most important plant species are the Morrison spurrey (Spergula morisonii Boreau) and the chickweed wintergreen (Trientalis europaea L.) - (AOPK, 2014).

The permanent research plots (PRP) are situated in altitude 410-425 $\mathrm{m}$ above sea level with south-east exposition and mean slope of 5 degrees. The location of PRPs 1-6 $50 \times 50 \mathrm{~m}$ is shown in Fig. 1. According to the forest management plan (2017-2026) the mean stand age of upper layer is 179 years, respectively 40 years of lower layer. Stand volume is $139 \mathrm{~m}^{3}$ $\mathrm{ha}^{-1}$ with $99 \%$ share of Scots pine and $1 \%$ of Norway spruce (Picea abies /L./ Karst.).

\section{Data Collection}

To determine the tree layer structure and natural regeneration, FieldMap technology (IFER-Monitoring and Mapping Solutions Ltd.) was used to establish 6 permanent research plots (PRPs) of $50 \times 50$ $\mathrm{m}(0.25 \mathrm{ha})$ size in 2006. The same technology was used for repeated measurements of these PRPs in 2016. The positions of all individuals of the tree layer with a diameter at breast height $(\mathrm{DBH}) \geq 4 \mathrm{~cm}$ were recorded. The height, height of the live crown base, and the crown projection were measured, at least in four directions perpendicular to each other. The diameter of the trees was measured with a metal calliper (accuracy $1 \mathrm{~mm}$ ) and the heights were measured using a Vertex laser hypsometer (accuracy $0.1 \mathrm{~m}$ ). From 25 dominant trees on each PRP, the core samples were randomly (RNG Excel) taken with Pressler

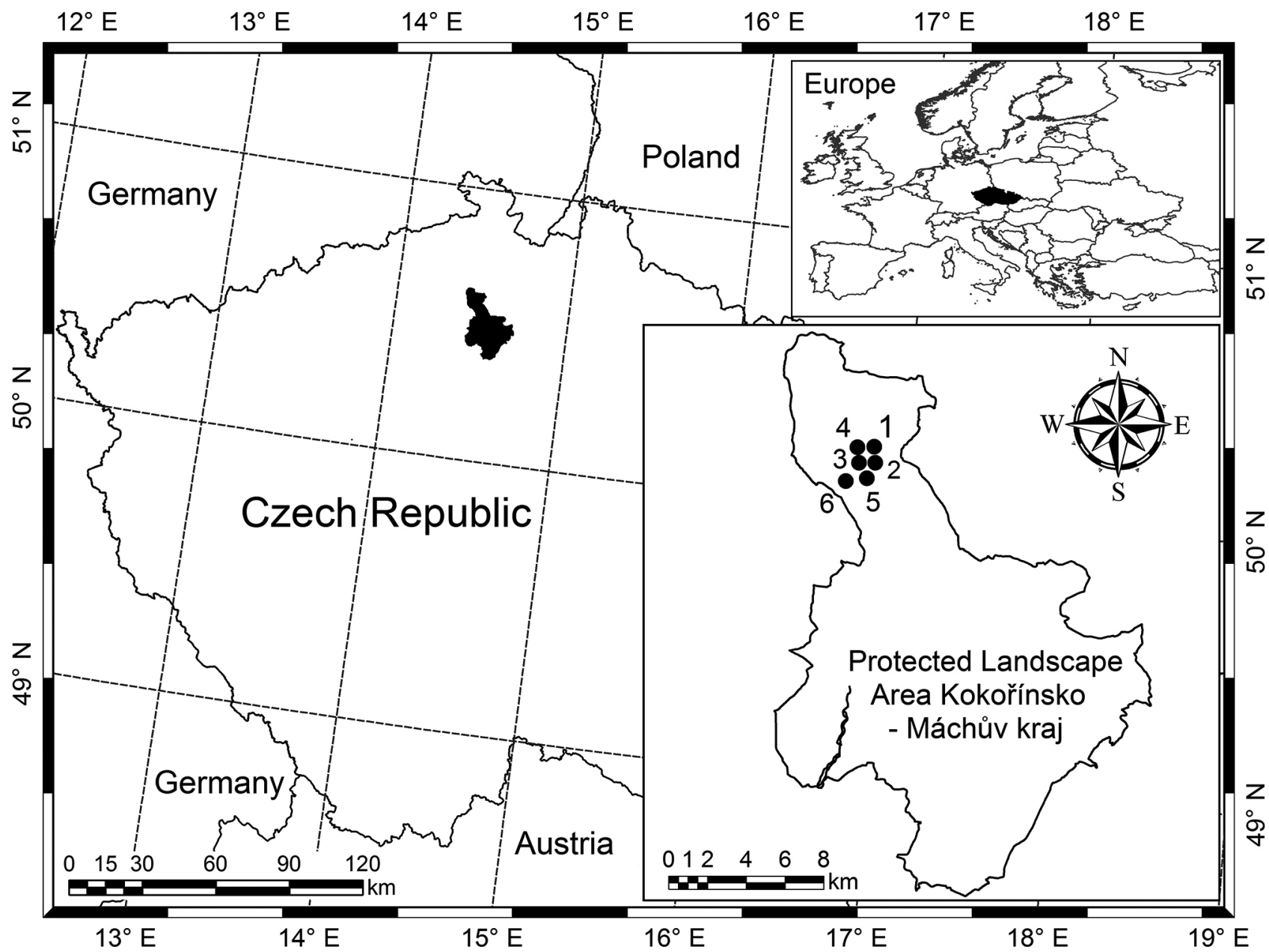

Fig. 1. Location of permanent research plots (PRP) 1-6 with natural pine forest stands in Nature Reserve Kostelecké bory in Protected Landscape Area Kokořínsko - Máchův kraj 
auger at $\mathrm{DBH}$ perpendicular to the axis of the tree along/against the slope. The annual ring width was measured (accuracy $0.01 \mathrm{~mm}$ ) using an Olympus binocular magnifying glass on a LINTAB measurement table and registered using the TSAPWin software (www.rinntech.com).

For dead wood, the degrees of decomposition (five-point scale: 1 - undisturbed trunk, 5 - final decay phase; the scale adjusted according to Spetich et al. (2001), its volume and share in the total stand volume were examined. The natural regeneration was measured in 2006 and in 2016 on individual PRPs at $10 \times 50 \mathrm{~m}$ transects that are representative from the point of regeneration. The following characteristics were measured for the natural regeneration: the position, the height, the height of live crown base and the width of the crown with height gauge rod (1 $\mathrm{cm}$ accuracy).

\section{Data processing}

Horizontal and vertical structure and species diversity of the tree layer, dead wood and natural regeneration of each PRP were evaluated. The basic stand characteristics of the tree layer were evaluated using the simulator SIBYLA Triquetra 10 (Fabrika \& Pretzsch, TUZVO). The PointPro 2.1 (Zahradnik \& Pus, CULS) program was used to calculate the characteristics of the horizontal layout of the individuals on the plot. The test of the significance of deviations from the values expected for the random arrangement of the points was made using Monte Carlo simulations. For the evaluation of biodiversity, the following indices were computed: index of non-randomness (Mountford, 1961), aggregation index (Clark \& Evans, 1954), index of cluster size (David \& Moore, 1954), indexes of diameter and height differentiation (Füldner, 1995), species richness index (Margalef, 1958), species heterogeneity index (Shanon, 1948), species evenness index (Pielou, 1959), Arten-profile index and total stand diversity index (Jaehne \& Dohrenbusch, 1997) (Table 1). Further, the stand density index (SDI), the crown closure (CC) and crown projection area (CPA) were calculated.

The annual growth ring width series were individually cross-dated (error correction associated with the absence of missing rings) using statistical tests in the PAST application (Knibbe, 2007) and subsequently subjected to visual inspection according to Yamaguchi (Yamaguchi, 1991). If a missing tree ring was found, a tree ring with a width of $0.01 \mathrm{~mm}$ was inserted in its place. The individual curves from the PRP were further de-trended in a standard way and the average annual series was created in the ARSTAN program (Laboratory of Tree-Ring Research). The 30-year spline was applied (Grissino-Mayer at al., 1992). Negative significant pointer years were analyzed according to Schweingruber (Schweingruber et al., 1990). For each tree, a significant year was identified as an extremely narrow tree ring, which did not reach $40 \%$ of the average tree ring widths from the previous 4 years. The occurrence of the negative year was proven if the strong reduction in growth occurred in at least $20 \%$ of the trees in the area. The average ring series of PRPs were correlated with the climatic data (precipitation, temperature) according to individual years from the Doksy station (19482016; $284 \mathrm{~m}$ a.s.l.), and the air pollution data $\left(\mathrm{SO}_{2}\right.$ in 1988-2015, $\mathrm{NO}_{\mathrm{x}}$ and AOT40F - ozone exposure in 1992-2015) from Radimovice station (378 m a.s.l.). DendroClim software (Biondi \& Waikul, 2004) was used to model the diameter increment depending on climatic characteristics.

In order to analyze the effect of overall meteorological conditions on the growth, Sielianinov hydrothermal coefficient $(K)$ was used (Radzka \& Rymuza, 2015). To determine the combined effect of average annual temperature and an annual sum of precipitation on diameter increment of pine, correlation quadratic model was used.

Table 1. Overview of the indexes describing the stand diversity and their common interpretation

\begin{tabular}{|c|c|c|c|c|}
\hline Criterion & Quantifiers & Label & Reference & Evaluation \\
\hline \multirow[t]{3}{*}{$\begin{array}{l}\text { Horizontal } \\
\text { structure }\end{array}$} & $\begin{array}{l}\text { Index of } \\
\text { non-randomness }\end{array}$ & $\alpha(\mathrm{P} \& \mathrm{Mi})$ & Mountford (1961) & mean value $\alpha=1$; aggregation $\alpha>1$; regularity $\alpha<1$ \\
\hline & $\begin{array}{l}\text { Aggregation } \\
\text { index }\end{array}$ & $R(\mathrm{C} \& \mathrm{Ei})$ & Clark and Evans (1954) & mean value $R=1$; aggregation $R<1$; regularity $R>1$ \\
\hline & $\begin{array}{l}\text { Index of cluster } \\
\text { size }\end{array}$ & CSI (D\&Mi) & David and Moore (1954) & $\begin{array}{l}\text { mean value } C S I=0 \text {; aggregation } C S I>0 \text {; regularity } \\
C S I<1\end{array}$ \\
\hline $\begin{array}{l}\text { Vertical } \\
\text { diversity }\end{array}$ & $\begin{array}{l}\text { Arten-profile } \\
\text { index }\end{array}$ & $A$ (Pri) & Pretzsch (2006) & $\begin{array}{l}\text { range } 0-1 \text {; balanced vertical structure } A<0.3 \text {; selection } \\
\text { forest } A>0.9\end{array}$ \\
\hline $\begin{array}{l}\text { Structure } \\
\text { differentiation }\end{array}$ & $\begin{array}{l}\text { Diameter dif. } \\
\text { Height dif. }\end{array}$ & $\begin{array}{l}T M_{d}(\mathrm{Fi}) \\
T M_{h}(\mathrm{Fi})\end{array}$ & Füldner (1995) & $\begin{array}{l}\text { range } 0-1 \text {; low } T M<0.3 \text {; very high differentiation } \\
T M>0.7\end{array}$ \\
\hline $\begin{array}{l}\text { Species } \\
\text { diversity }\end{array}$ & $\begin{array}{l}\text { Richness } \\
\text { Heterogeneity } \\
\text { Evenness }\end{array}$ & $\begin{array}{l}\text { D (Mai) } \\
H^{\prime} \text { (Shi) } \\
\text { E (Pii) }\end{array}$ & $\begin{array}{l}\text { Margalef (1958) } \\
\text { Shannon (1948) } \\
\text { Pielou (1975) }\end{array}$ & $\begin{array}{l}\text { minimum } D=0 \text {, higher } D=\text { higher values } \\
\text { minimum } H^{\prime}=0 \text {, higher } H^{\prime}=\text { higher values } \\
\text { range } 0-1 \text {; minimum } E=0 \text {, maximum } E=1\end{array}$ \\
\hline $\begin{array}{l}\text { Complex } \\
\text { diversity }\end{array}$ & Stand diversity & $B(J \& \mathrm{Di})$ & $\begin{array}{l}\text { Jaehne and Dohrenbusch } \\
\text { (1997) }\end{array}$ & $\begin{array}{l}\text { monotonous structure } B<4 \text {; uneven structure } B=6-8 \text {; } \\
\text { very diverse structure } B>9\end{array}$ \\
\hline
\end{tabular}


Stanislav Vacek et al.

Table 2. Basic stand characteristics of pine forest on individual permanent research plots 1-6 in 2006 and 2016

\begin{tabular}{cccccccccccccc}
\hline \multirow{2}{*}{ PRP } & \multirow{2}{*}{ Year } & Age & $\mathrm{dbh}$ & $\mathrm{h}$ & $\mathrm{v}$ & $\mathrm{N}$ & $\mathrm{BA}$ & $\mathrm{V}$ & $\mathrm{HDR}$ & $\mathrm{MAI}$ & CC & CPA & SDI \\
\hline & & $\mathrm{y}$ & $\mathrm{cm}$ & $\mathrm{m}$ & $\mathrm{m}^{3}$ & trees ha & $\mathrm{m}^{2} \mathrm{ha}^{-1}$ & $\mathrm{~m}^{3} \mathrm{ha}^{-1}$ & & $\mathrm{~m}^{3} \mathrm{ha}^{-1} \mathrm{y}^{-1}$ & $\%$ & ha & \\
\hline \multirow{2}{*}{1} & 2006 & 195 & 21.1 & 11.1 & 0.230 & 624 & 21.8 & 143 & 52.6 & 0.73 & 77.0 & 1.47 & 0.48 \\
& 2016 & 201 & 22.9 & 11.9 & 0.281 & 624 & 25.8 & 176 & 52.0 & 0.88 & 78.1 & 1.52 & 0.55 \\
2 & 2006 & 201 & 19.6 & 10.5 & 0.205 & 720 & 21.6 & 148 & 53.6 & 0.74 & 78.5 & 1.54 & 0.49 \\
& 2016 & 206 & 21.4 & 11.2 & 0.252 & 724 & 26.0 & 183 & 52.3 & 0.89 & 80.2 & 1.62 & 0.57 \\
\multirow{2}{*}{3} & 2006 & 183 & 19.4 & 12.4 & 0.221 & 560 & 16.5 & 124 & 63.9 & 0.67 & 72.3 & 1.29 & 0.36 \\
& 2016 & 187 & 21.3 & 13.3 & 0.274 & 560 & 19.9 & 153 & 62.4 & 0.82 & 74.2 & 1.35 & 0.42 \\
4 & 2006 & 172 & 22.0 & 12.7 & 0.295 & 316 & 12.0 & 93 & 57.7 & 0.54 & 57.8 & 0.86 & 0.25 \\
& 2016 & 178 & 23.7 & 13.5 & 0.352 & 324 & 14.2 & 114 & 57.0 & 0.64 & 57.9 & 0.86 & 0.29 \\
5 & 2006 & 154 & 17.3 & 8.5 & 0.134 & 572 & 13.4 & 76 & 49.1 & 0.49 & 66.8 & 1.10 & 0.31 \\
& 2016 & 159 & 18.8 & 9.3 & 0.165 & 608 & 16.9 & 100 & 49.5 & 0.64 & 71.3 & 1.25 & 0.38 \\
6 & 2006 & 163 & 13.7 & 7.9 & 0.074 & 836 & 12.2 & 62 & 57.7 & 0.38 & 68.3 & 1.15 & 0.32 \\
& 2016 & 165 & 14.7 & 8.4 & 0.088 & 996 & 17.0 & 88 & 57.1 & 0.53 & 74.1 & 1.35 & 0.43 \\
\hline
\end{tabular}

Notes: age - weighted arithmetic mean of ages of the trees forming the particular stand component, dbh - mean quadratic breast height diameter, $\mathrm{h}$ - mean height, $\mathrm{v}$ - average tree volume, $\mathrm{N}$ - number of trees per hectare, BA - basal area, $\mathrm{V}$ - stand volume, HDR - slenderness ratio, MAI - mean annual increment, CC - canopy closure, CPA - crown projection area, SDI - stand density index.

In order to determine the response of the stand health status to site conditions, the climatic data (the sum of precipitation and mean temperatures in the current and previous year), air pollution factors $\left(\mathrm{SO}_{2}\right.$ concentrations, $\mathrm{NO}_{\mathrm{x}}$ concentration, AOT40F) and radial growth were tested for correlations in the software Statistica 12 (StatSoft). Unconstrained principal component analysis (PCA) in Canoco 5 program (Šmilauer \& Lepš, 2014) was used to analyze the relationships among climatic data, $\mathrm{SO}_{2}$ concentrations, $\mathrm{NO}_{\mathrm{x}}$ concentration, ozone exposure and the ring width. The data were log-transformed, centered and standardized before the analysis. The results of the PCA analysis were visualized in the form of an ordination diagram.

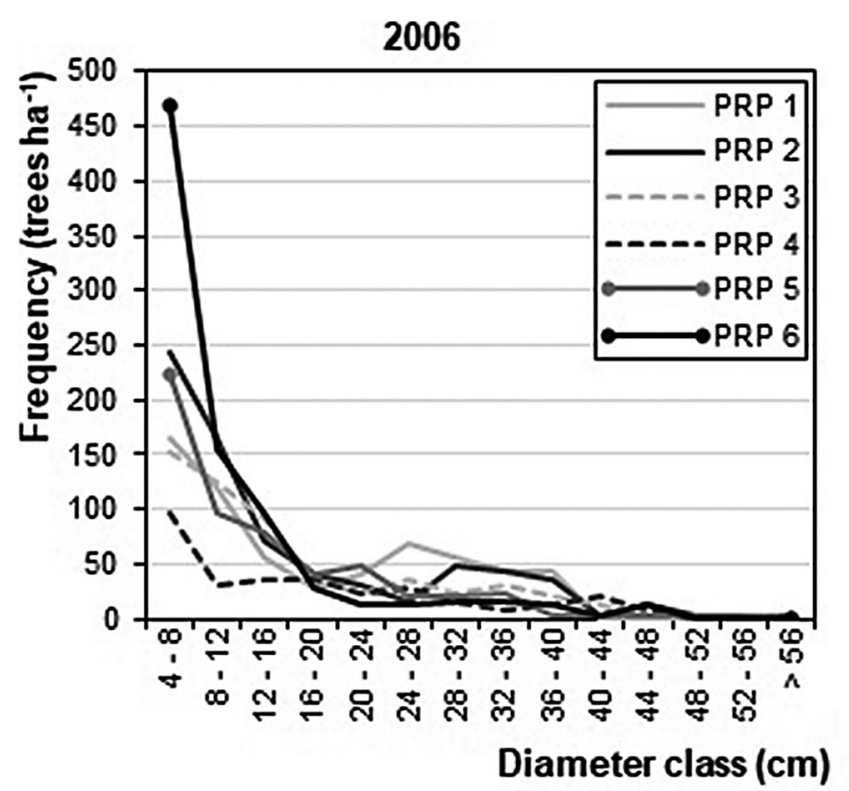

\section{Results}

\section{Tree Layer Structure and Production}

In 2006, the stand density ranged from 316 to 836 trees ha- (for pine it was 224-756 trees ha-1) with a stand density index (SDI) of 0.25-0.49 (Table 2). The stand volume was $62-148 \mathrm{~m}^{3} \mathrm{ha}^{-1}$, of which $61-147$ $\mathrm{m}^{3} \mathrm{ha}^{-1}$ were pines, $8-9 \mathrm{~m}^{3} \mathrm{ha}^{-1}$ were spruces (PRP 3-5 only) and the rest was formed by silver birch (Betula pendula Roth). The highest stand volume was found on PRP 2, where it reached $148 \mathrm{~m}^{3} \mathrm{ha}^{-1}$ and the lowest on PRP $6,62 \mathrm{~m}^{3} \mathrm{ha}^{-1}$. The highest stand volume of pine was also found on PRP $2\left(147 \mathrm{~m}^{3}\right.$ $\left.\mathrm{ha}^{-1}\right)$ and the lowest on PRP $6\left(61 \mathrm{~m}^{3} \mathrm{ha}^{-1}\right)$. The stand basal area ranged from $12.0-21.8 \mathrm{~m}^{2} \mathrm{ha}^{-1}$ (pine

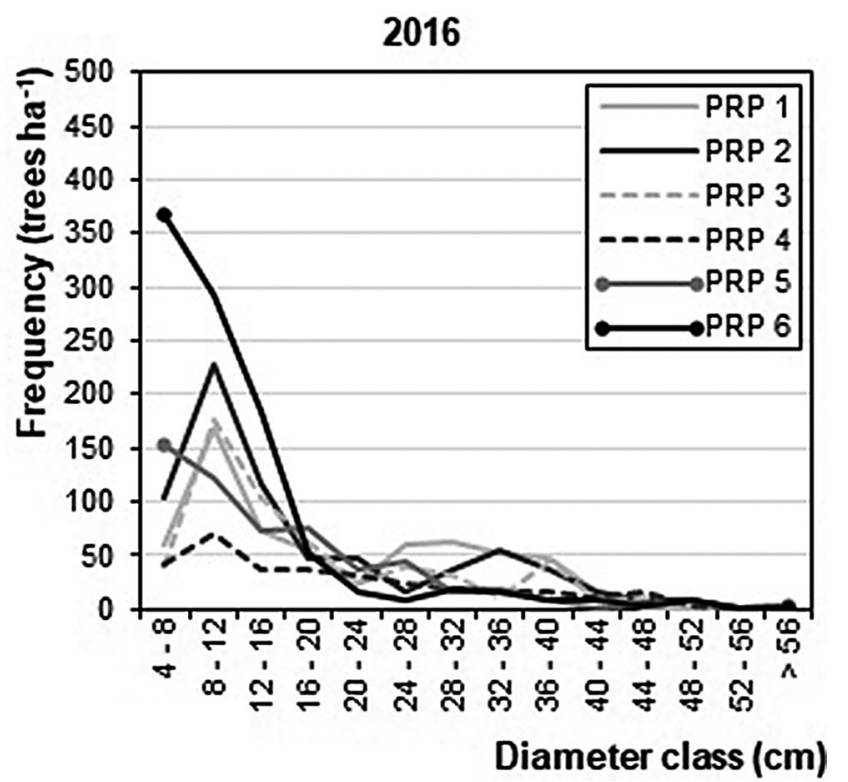

Fig. 2. Histograms of diameter structure of the tree layer on permanent research plots 1-6 Kostelecké bory in 2006 and 2016 
9.1-21.4 $\left.\mathrm{m}^{2} \mathrm{ha}^{-1}\right)$ and the mean annual increment was $0.4-0.7 \mathrm{~m}^{3} \mathrm{ha}^{-1} \mathrm{y}^{-1}$ (pine $0.4-0.7 \mathrm{~m}^{3} \mathrm{ha}^{-1} \mathrm{y}^{-1}$ ).

In 2016, number of live trees ranged from 324 to 996 trees ha $^{-1}$ (pine 224-884 trees ha ${ }^{-1}$ ) with SDI of 0.29-0.57 (Table 2). The stand volume was 88$183 \mathrm{~m}^{3} \mathrm{ha}^{-1}$, of which $84-182 \mathrm{~m}^{3} \mathrm{ha}^{-1}$ were pines, 12-14 $\mathrm{m}^{3} \mathrm{ha}^{-1}$ spruces (PRP only $3-5$ ), and the rest was formed by birch. The highest stand volume was found on PRP 2 with $183 \mathrm{~m}^{3} \mathrm{ha}^{-1}$ (pine $182 \mathrm{~m}^{3}$ $\left.\mathrm{ha}^{-1}\right)$ and the lowest on PRP 6 with $88 \mathrm{~m}^{3} \mathrm{ha}^{-1}(84$ $\left.\mathrm{m}^{3} \mathrm{ha}^{-1}\right)$. The stand basal area ranged from 14.2 to $26.0 \mathrm{~m}^{2} \mathrm{ha}^{-1}$ (pine 10.5-25.7 $\mathrm{m}^{2} \mathrm{ha}^{-1}$ ) and the mean annual increment was $0.5-0.9 \mathrm{~m}^{3} \mathrm{ha}^{-1} \mathrm{y}^{-1}$ (the pine is $\left.0.4-0.9 \mathrm{~m}^{3} \mathrm{ha}^{-1} \mathrm{y}^{-1}\right)$. In 2016, the canopy classification ranged from 0.58 to 0.80 in crown closure and from 0.86 to 1.62 in crown area. Comparing year 2006 and 2016, the highest increase was observed in stand volume $(+26.0 \%)$ and in basal area $(+22.9 \%)$, while it was the lowest in crown closure $(+3.6 \%)$, followed by number of trees $(+5.7 \%)$.

The highest pine trees reached a height of 20-23 $\mathrm{m}$. The highest individuals of admixed spruce on PRPs 3 and 4 reached 20-22 m, but spruce mostly occurred in the middle storey. The birch was predominantly in the middle storey with the highest individuals between 13-15 m. In the course of 10 years, the average height increase of pine and spruce was up to $1.0 \mathrm{~m}$, in case of birch, it was 1.2-1.8 m. In terms of the diameter structure, the diameter class of $4-8 \mathrm{~cm}$ prevailed in 2006, only on the PRP 3 prevailed the diameter class of 8-12 cm (Fig. 2). The average DBH of the trees at the PRP was $21.3-23.7 \mathrm{~cm}$, in case of pine, it was $21.6-24.41 \mathrm{~cm}$ and the spruce $14.4-17.9 \mathrm{~cm}$.

\section{Tree Layer Biodiversity}

In 2016, the vertical structure according to $A$ index was moderately diverse (index values $0.55-0.62$ ) on PRPs 1-5 and highly varied on PRP 6 (0.72; Table 3). Diameter differentiation $T M_{d}$ was predominantly medium (0.29-0.35) and height differentiation $T M_{h}$ was low on PRPs 1-4 and 6 (0.22-0.29), only on PRP 5 it was medium (0.33). In terms of species diversity according to $H^{\prime}$ entropy, the species heterogeneity was very low on PRPs 1 and 2 (0.03-0.08), low on PRPs 3, 5 and $6(0.11-0.23)$ and PRP 4 had medium biodiversity (0.37). On the basis of species evenness $E$, PRPs 1 and 2 had low diversity (0.10-0.27), PRPs 3,5 and 6 had medium diversity $(0.35-0.47)$ and PRP 4 was of high biodiversity (0.61). The total complex diversity $B$ indicated uneven stand structure (6.347.10), only PRP 6 has even stand structure (5.9). The biodiversity of the tree layer changed between 2006 and 2016. Generally, biodiversity increased during the time on PRPs $(+2.8 \%)$, especially in species heterogeneity $H^{\prime}(+5.1 \%)$ and height differentiation $T M_{h}(+3.3 \%)$. In total diversity $B$, as the only one, increase was monitored on all PRPs $(+1.2 \%)$.

The horizontal structure of the tree layer in 2006 and 2016, according to valuated $\alpha, R$ and CSI indices, is predominantly random on PRPs (Table 3, Fig. 3). An exception is PRP 2 and 6 with the highest stand density, where the distribution of trees was aggregated. During stand dynamics, the horizontal structure of the tree layer changed only slightly with no apparent trend to clustering or more regular horizontal structure (Table 3 ).

\section{Interactions of Radial Growth, Climate Factors and Air Pollution}

The average tree ring width in the years 1800 2016 on PRP 1 was $0.65 \mathrm{~mm}$ ( \pm 0.5 SD), PRP 20.77 $\mathrm{mm}( \pm 0.3 \mathrm{SD})$, PRP $30.68 \mathrm{~mm}( \pm 0.4 \mathrm{SD})$, PRP 4 values $0.77 \mathrm{~mm}( \pm 0.3 \mathrm{SD})$, PRP 5 values of 0.96

Table 3. Biodiversity indices of pine forest stands on permanent research plots 1-6 in 2006 and 2016

\begin{tabular}{|c|c|c|c|c|c|c|c|c|c|c|c|c|c|c|c|c|c|c|c|}
\hline PRP & Year & A & & $\mathrm{TM}_{\mathrm{d}}$ & & $\mathrm{TM}_{\mathrm{h}}$ & & $\mathrm{H}^{\prime}$ & & $\mathrm{E}$ & & $\alpha^{*}$ & & $\mathrm{R}^{*}$ & & $\mathrm{CSI}^{*}$ & & B & \\
\hline \multirow[t]{2}{*}{1} & 2006 & 0.556 & \multirow{2}{*}{$\nearrow$} & 0.291 & \multirow{2}{*}{$\nearrow$} & 0.243 & \multirow{2}{*}{$\nearrow$} & & \multirow{2}{*}{$\nearrow$} & 0.253 & \multirow{2}{*}{$\nearrow$} & 0.943 & \multirow{2}{*}{$\nearrow$} & 1.063 & \multirow{2}{*}{$\searrow$} & 0.058 & \multirow{2}{*}{$\searrow$} & & \multirow{2}{*}{$\nearrow$} \\
\hline & 2016 & 0.573 & & 0.297 & & 0.255 & & 0.081 & & 0.269 & & 0.970 & & 1.040 & & 0.053 & & 6.366 & \\
\hline \multirow[t]{2}{*}{2} & 2006 & 0.566 & \multirow{2}{*}{$\searrow$} & 0.321 & \multirow{2}{*}{$\searrow$} & 0.288 & \multirow{2}{*}{$\searrow$} & 0.026 & \multirow{2}{*}{$\nearrow$} & 0.091 & \multirow{2}{*}{$\nearrow$} & $1.343^{\mathrm{A}}$ & \multirow{2}{*}{$\searrow$} & $0.933^{A}$ & \multirow{2}{*}{$\nearrow$} & $0.372^{\mathrm{A}}$ & \multirow{2}{*}{$\searrow$} & 6.461 & \multirow{2}{*}{$\nearrow$} \\
\hline & 2016 & 0.551 & & 0.315 & & 0.278 & & 0.029 & & 0.096 & & $1.332^{\mathrm{A}}$ & & $0.941^{\mathrm{A}}$ & & $0.358^{\mathrm{A}}$ & & 6.483 & \\
\hline \multirow[t]{2}{*}{3} & 2006 & 0.557 & \multirow{2}{*}{$\nearrow$} & 0.378 & \multirow{2}{*}{$\searrow$} & 0.293 & \multirow{2}{*}{$\searrow$} & 0.229 & \multirow{2}{*}{$\searrow$} & 0.457 & \multirow{2}{*}{$\searrow$} & 1.337 & \multirow{2}{*}{$\searrow$} & 0.982 & \multirow{2}{*}{$\nearrow$} & 0.229 & \multirow{2}{*}{$\searrow$} & 6.382 & \multirow{2}{*}{$\nearrow$} \\
\hline & 2016 & 0.583 & & 0.351 & & 0.287 & & 0.212 & & 0.444 & & 1.303 & & 0.998 & & 0.212 & & 6.500 & \\
\hline \multirow[t]{2}{*}{4} & 2006 & 0.605 & \multirow{2}{*}{$\nearrow$} & 0.337 & \multirow{2}{*}{$\nearrow$} & 0.261 & & 0.342 & & 0.601 & & 1.123 & & 1.014 & & 0.056 & & 7.063 & \\
\hline & 2016 & 0.624 & & 0.351 & & 0.287 & & 0.365 & $r$ & 0.606 & 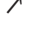 & 1.102 & $\searrow$ & 1.030 & $r$ & 0.065 & $\gamma$ & 7.104 & $\nearrow$ \\
\hline 5 & 2006 & 0.613 & $\pi$ & 0.347 & $\pi$ & 0.318 & $\pi$ & 0.203 & $\pi$ & 0.452 & $\pi$ & 1.243 & & 0.938 & $\pi$ & 0.216 & & 6.841 & $\pi$ \\
\hline & 2016 & 0.631 & & 0.373 & & 0.333 & & 0.225 & & 0.472 & & 1.267 & $\gamma$ & 0.980 & & 0.206 & y & 6.964 & \\
\hline 6 & 2006 & 0.703 & $\pi$ & 0.264 & $\pi$ & 0.203 & $\pi$ & 0.101 & $\pi$ & 0.338 & $\pi$ & $2.502^{\mathrm{A}}$ & $\pi$ & $0.853^{\mathrm{A}}$ & $\pi$ & $1.799^{\mathrm{A}}$ & $\pi$ & 5.798 & \\
\hline & 2016 & 0.720 & & 0.286 & & 0.215 & $\gamma$ & 0.106 & 7 & 0.352 & r & $2.538^{A}$ & 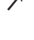 & $0.886^{A}$ & $r$ & $1.860^{\mathrm{A}}$ & $r$ & 5.853 & \\
\hline
\end{tabular}

Notes: A (Pri) - Arten-profile index, $\mathrm{TM}_{\mathrm{d}}(\mathrm{Fi})$ - diameter differentiation, $\mathrm{TM}_{\mathrm{h}}(\mathrm{Fi})$ - height differentiation, $\mathrm{H}^{\prime}$ (Shi) - species heterogeneity, E (Pii) - species evenness, $\alpha$ (P\&Mi) - index of non-randomness, R (C\&Ei) - aggregation index, CSI (D\&Mi) - index of cluster size, B (J\&Di) - total stand diversity.

*statistically significant for horizontal structure ( ${ }^{\mathrm{A}}$ - aggregation, ${ }^{\mathrm{R}}$ - regularity); changes: $\searrow-$ decrease, $\nearrow-$ increase. 

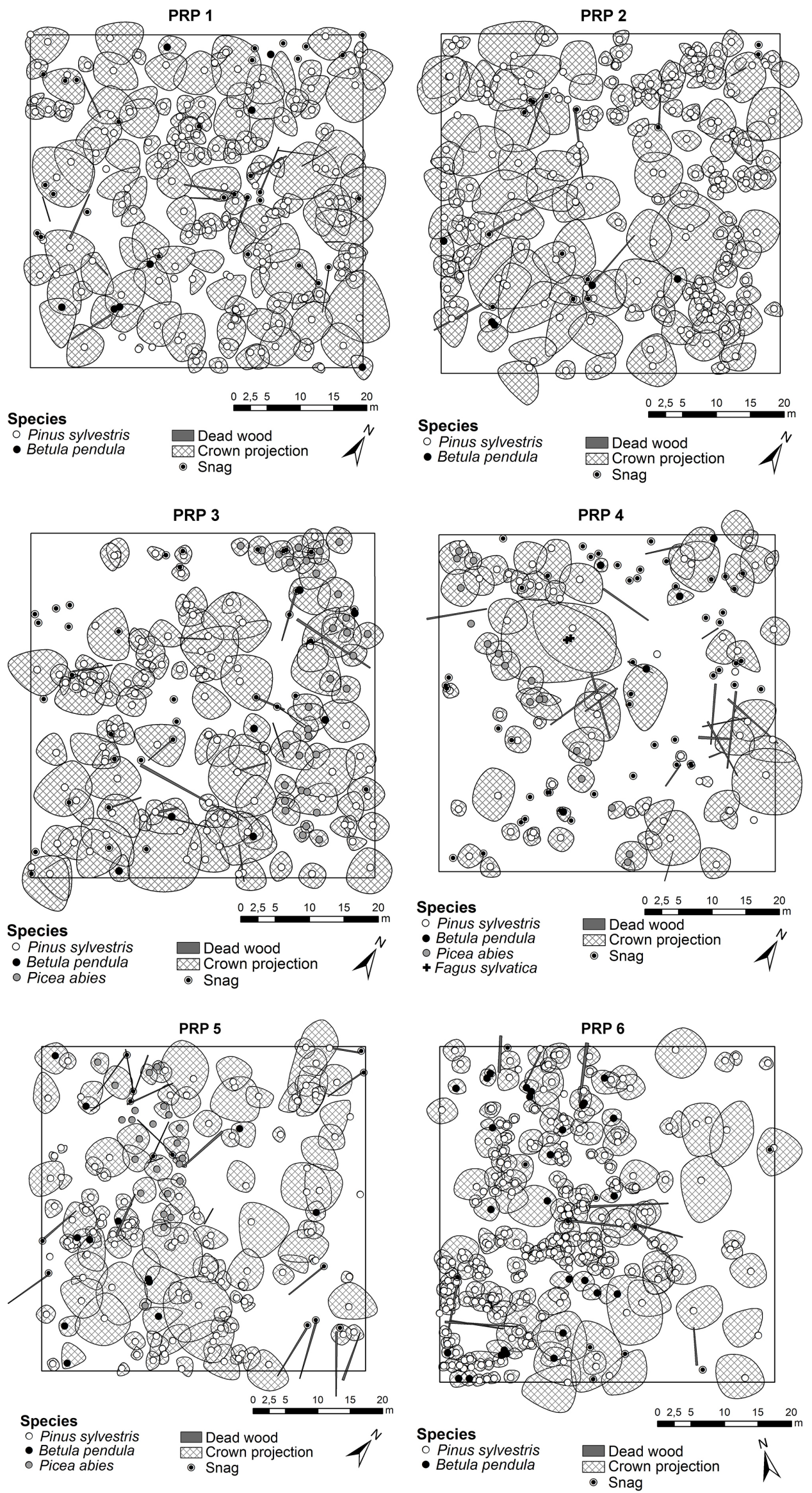

Fig. 3. Horizontal structure of natural pine stands on permanent research plots 1-6 in Kostelecké bory in 2016 
$\mathrm{mm}( \pm 0.3 \mathrm{SD})$, and PRP 6 values of $0.72 \mathrm{~mm}( \pm 0.4$ $\mathrm{SD})$. Comparison of the average ring-width curves for individual PRPs showed their high reliability of synchronization. From the regional standardized dendrochronology, there is obvious a relatively heterogenous radial growth in the years 1800-2016 (Fig. $4)$. The age of the upper layer pine trees was between 237-264 years. The years 1976 were analysed as negative pointer years for low radial growth of pine (January-July precipitation amount $161 \mathrm{~mm}$, mean 340 $\mathrm{mm}$ in 1948-2016).

Correlations of diameter increment with the average monthly temperatures and precipitation in 1948-2016 indicated some statistically significant values from software Dendroclim (Fig. 5). There were significant negative correlations of diameter increment with temperature in September of the previous year $(\mathrm{r}=-0.29)$ and in January of the current year $(r=-0.23)$. Conversely, precipitation amount had a predominantly significant positive effect on radial growth, especially in June and July of the previous year $(r=0.22$ and 0.27$)$ and from May to July of the current year $(r=0.22-0.34)$. The negative effect of the precipitation was observed only in November of the previous year ( $r=-0.22$, Fig. 5$)$.

The main factor influencing the diameter increment of pine in the study area was identified as the precipitation (Fig. 6). Diameter increment only slightly increased with increasing annual mean temperature, while the considerable increase of growth was observed with increasing annual sum of precipitation. According to hydrothermal index $K$, climate (combination of temperature and precipitation) had significant positive impact on radial growth in July of the current year $(\mathrm{r}=0.37, \mathrm{P}<0.01)$ and June of the current and previous year $(\mathrm{r}=0.24-29, \mathrm{P}<0.05)$.

In addition to climatic factors, air pollution had significant effect on radial growth. Diameter increment was significantly negatively correlated with $\mathrm{SO}_{2}$ concentrations (1988-2015), especially in growing season $(\mathrm{r}=-0.56, \mathrm{P}<0.001)$. In terms of month $\mathrm{SO}_{2}$ concentrations, there was no significant correlation of radial growth with December, January, and February $(\mathrm{P}>0.05)$, while significant negative correlation was observed in all other months with the highest negative effect in July $(r=-0.58, \mathrm{P}<0.001)$.

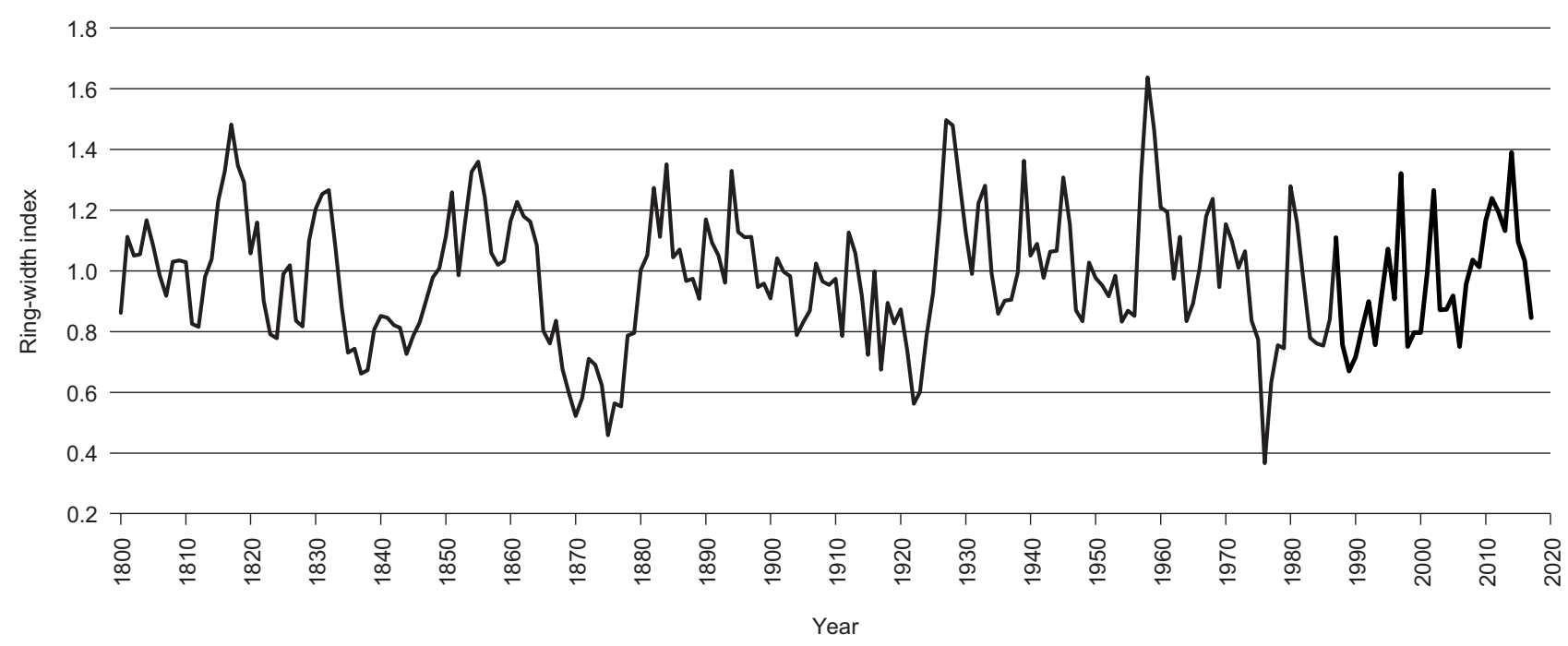

Fig. 4. Standardized average ring width chronology for pine after age detrending in period 1800-2016
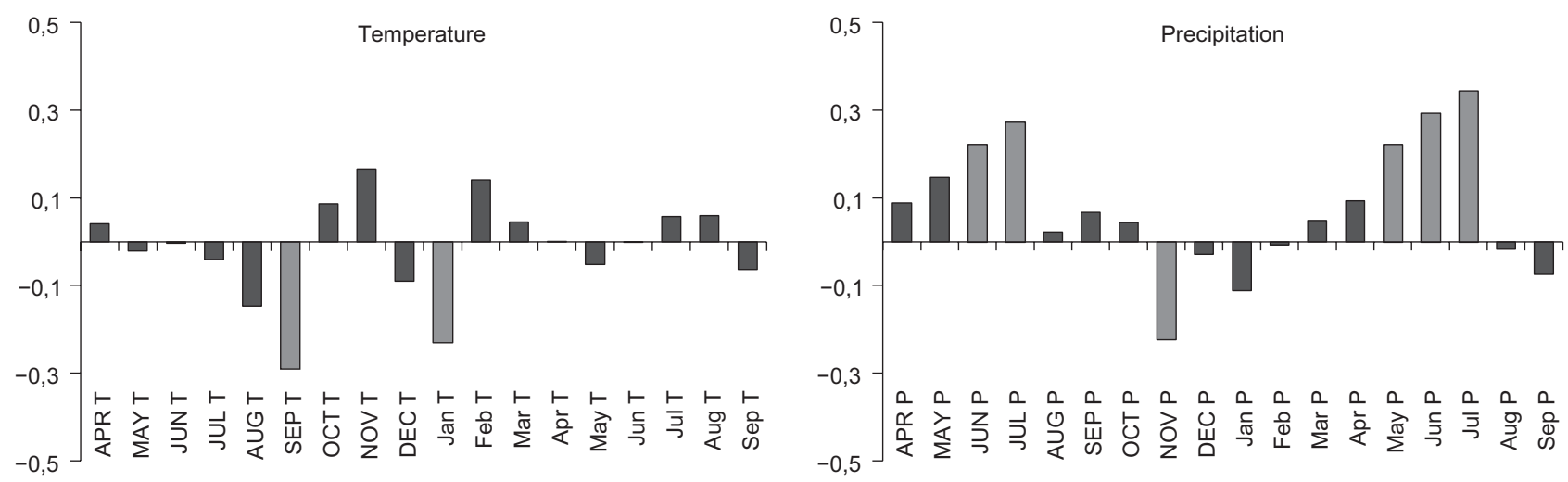

Fig. 5. The values of correlation coefficients of the regional residual index tree ring chronology with the monthly temperatures and precipitation (period 1948-2016) from May of the previous year (capital letter) to September of the current year (small letters). Significant values are displayed by light grey colour $(\alpha=0.05)$ 


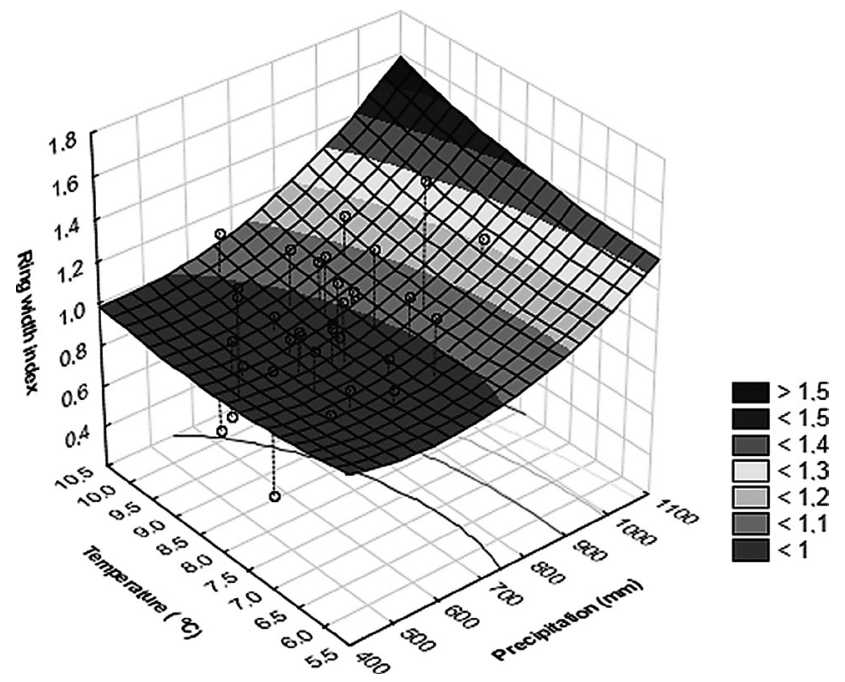

Fig. 6. Response of ring width index of pine to the annual sum of precipitation and annual mean temperature (correlation quadratic model, years 1948-2016)

Similarly radial growth was negatively correlated with ozone exposure (1992-2015), especially in April $(\mathrm{r}=-0.56, \mathrm{P}<0.01)$ and May $(\mathrm{r}=-0.51$, $\mathrm{P}<0.01)$. On the contrary significant $\mathrm{NO}_{\mathrm{X}}$ effect $(\mathrm{P}>0.05)$ on radial growth was not detected. Diameter increment was also significantly $(P<0.01)$ positively correlated with the sum of precipitation in the current and previous growing season and with the sum of precipitation from May to August of both years (1948-2016). No significant effect $(P>0.05)$ of temperature on diameter increment was observed in any time period (Table 4).

Results of the PCA are presented in an ordination diagram in Fig. 7. The first ordination axis explains $23.7 \%$ of the variability in the data, the first two axes together $43.4 \%$ and the first four axes together $69.9 \%$. The first axis $\mathrm{x}$ represents annual ring width, the sum of precipitation in growing season of the previous year with ozone exposure. The second axis y represents $\mathrm{NO}_{\mathrm{x}}$ concentrations with mostly temperature indicators. Radial growth was positively correlated with precipitation in growing season and from May to

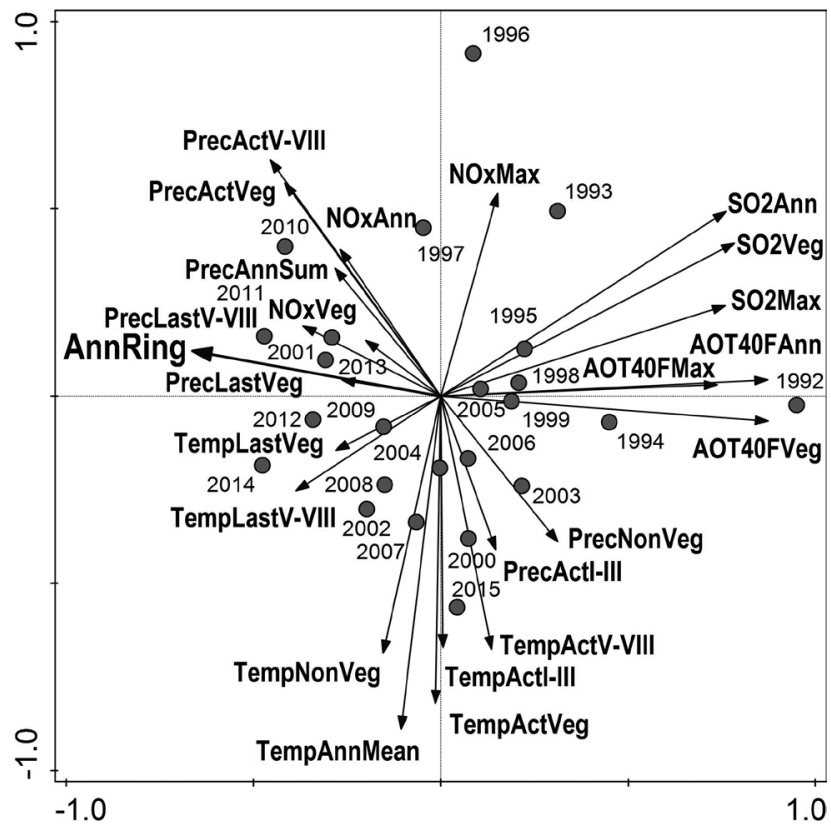

Fig. 7. Ordination diagram showing the results of principal component analysis of the relationships among climatic data (Temp - mean temperature, Prec - sum of precipitation, Act - current year, Last - last year, Veg - vegetation season, NonVeg - non-vegetation season, Sum - summary; I-III, V-VIII months), air pollutants $\left(\mathrm{SO}_{2} \mathrm{Ann}\right.$ - mean annual $\mathrm{SO}_{2}$ concentrations, $\mathrm{SO}_{2} \mathrm{Veg}-$ mean $\mathrm{SO}_{2}$ concentrations in vegetation season, $\mathrm{SO}_{2} \mathrm{Max}$ - maximal annual $\mathrm{SO}_{2}$ concentrations; $\mathrm{NO}_{X}-\mathrm{NO}_{\mathrm{X}}$ concentrations, AOT4OF - ozone exposure) and ring width (AnnRing annual ring width); codes $\bullet$ indicate years 1992-2015

August of the previous and current year, while these parameters were negatively correlated with $\mathrm{SO}_{2}$ concentrations and ozone exposure. $\mathrm{NO}_{\mathrm{x}}$ concentrations had low effect on radial growth. With respect to time, radial growth during the first third of the investigated period (the 1990s) was related more to strong air pollution $\left(\mathrm{SO}_{2}\right.$ concentrations and ozone exposure), whereas during the second part of the investigated period (2000s, 2010s) it was related more to climatic factors. The lowest contribution of interactions was observed in $\mathrm{NO}_{\mathrm{x}}$ concentrations in growing season.

Table 4. Correlations between the radial growth increment of pine with climatic data (1948-2016) and air pollution factors ( $\mathrm{SO}_{2}$ 1988-2015; AOT40F, $\mathrm{NO}_{\mathrm{x}}$ 1992-2015); significant correlations are in bold $(\mathrm{P}<0.05)$ and underlined $(\mathrm{P}<0.01)$

\begin{tabular}{|c|c|c|c|c|c|c|c|c|c|c|c|c|c|c|c|c|}
\hline & $\begin{array}{l}\mathrm{SO}_{2} \\
\mathrm{Veg}\end{array}$ & $\begin{array}{l}\mathrm{SO}_{2} \\
\mathrm{Ann}\end{array}$ & $\begin{array}{l}\mathrm{SC} \\
\mathrm{Mc}\end{array}$ & $\begin{array}{l}\mathrm{O}_{2} \\
\operatorname{lax} \\
\end{array}$ & & $\begin{array}{l}\mathrm{O}_{\mathrm{x}} \\
\mathrm{yeg}\end{array}$ & $\begin{array}{l}\mathrm{N} \\
\mathrm{Ar}\end{array}$ & $\begin{array}{l}\mathrm{O}_{\mathrm{x}} \\
\mathrm{nn}\end{array}$ & $\begin{array}{l}\mathrm{NO} \\
\mathrm{Ma}\end{array}$ & $\begin{array}{r}\mathrm{AO} \\
\mathrm{V}\end{array}$ & $\begin{array}{l}40 \mathrm{~F} \\
\mathrm{eg}\end{array}$ & $\begin{array}{c}\text { AOT40F } \\
\text { Ann }\end{array}$ & $\begin{array}{c}\text { AOT40F } \\
\text { Max }\end{array}$ & $\begin{array}{c}\text { Temp } \\
\text { ActAnn }\end{array}$ & $\begin{array}{c}\text { Temp } \\
\text { ActVeg }\end{array}$ & $\begin{array}{c}\text { Temp } \\
\text { LastVeg }\end{array}$ \\
\hline \multirow[t]{2}{*}{ Increment } & -0.56 & -0.53 & & .48 & & 0.10 & & .04 & -0 . & & .42 & -0.51 & -0.45 & 0.05 & 0.03 & -0.07 \\
\hline & $\begin{array}{c}\text { Temp } \\
\text { ActV-VIII }\end{array}$ & $\begin{array}{r}\text { Tel } \\
\text { Lastl }\end{array}$ & & $\begin{array}{l}\text { Ter } \\
\text { Actl }\end{array}$ & & $\begin{array}{r}\text { Ter } \\
\text { Non }\end{array}$ & & $\begin{array}{r}\mathrm{Pr} \\
\text { ActS }\end{array}$ & & $\begin{array}{c}\text { Prec } \\
\text { ActVeg }\end{array}$ & & $\begin{array}{r}\mathrm{Pr} \\
\text { ActV }\end{array}$ & $\begin{array}{r}\mathrm{Pr} \\
\text { Last }\end{array}$ & $\begin{array}{l}\text { ec } \\
\text {--VIII }\end{array}$ & $\begin{array}{l}\text { Prec } \\
\text { ctI-III }\end{array}$ & $\begin{array}{c}\text { Prec } \\
\text { Nonveg }\end{array}$ \\
\hline Increment & 0.07 & -0 & & 0. & & 0. & & 0.1 & & $\underline{0.33}$ & & 41 & & & 0.01 & 0.01 \\
\hline
\end{tabular}

Notes: $\mathrm{SO}_{2} \mathrm{Veg}$ - mean $\mathrm{SO}_{2}$ concentrations in vegetation season, $\mathrm{SO}_{2} \mathrm{Ann}$ - mean annual $\mathrm{SO}_{2}$ concentrations, $\mathrm{SO}_{2} M a x-$ maximal annual $\mathrm{SO}_{2}$ concentrations, $\mathrm{NO}_{X}-\mathrm{NO}_{\mathrm{X}}$ concentrations, AOT4OF - ozone exposure, TempActAnn - mean annual temperature, TempActVeg mean temperature in the current vegetation season, TempLastVeg - mean temperature in the previous vegetation season, TempActVVIII - mean temperature in May-August of the given year, TempLastV-VIII - mean temperature in May-August of the previous year, TempActI-III - mean temperature in January-March of the given year, TempNonveg - mean temperature in the non-vegetation season (from October of the previous year to March of the given year); Prec - sum of precipitation. 
The dynamics of parameters in the course of 24 years was remarkable especially for the period from 1992 to 1998 as marks of each record are relatively distant from one another whereas marks after the year 1998 were relatively closer together in the diagram.

\section{Structure and Dynamics of Dead wood}

The volume of dead wood ranged in 2016 between 15.8-39.3 $\mathrm{m}^{3} \mathrm{ha}^{-1}$ (Table 5). Dead wood volume accounts for $8.0-25.6 \%$ of the total wood volume (live and dead trees). The percentage of lying dead wood ranged between $22.0-58.2 \%$ ( $41.9 \%$ on average) of the total dead wood volume. Overall, the share of standing dead wood prevailed $(58.2 \%)$. Dead wood consisted of pine $(93.4 \%)$, spruce $(4.7 \%)$ and birch (1.9\%). Of the lying dead wood, there were $56.3 \%$ in the $4^{\text {th }}$ stage of decay, $25.4 \%$ in the $3^{\text {rd }}$ stage, $11.7 \%$ in the stage $5,5.7 \%$ in stage 2 and $0.9 \%$ in stage 1 (Table 5).

The proportion of standing dead wood ranged from $41.8-78.0 \%$ of the total dead wood volume. Standing dead wood was mainly pine $(96.5 \%)$ and the rest was spruce. The most volume of dead wood was in the $2^{\text {nd }}$ degree of decomposition (61.8\%), in the $3^{\text {rd }}$ degree it was $26.0 \%$, in the $1^{\text {st }}$ degree $11.6 \%$ and in the $4^{\text {th }}$ degree $0.6 \%$. The horizontal structure of the standing and lying dead wood was random on all PRPs.

The total volume of dead wood in 2006 was significantly lower in comparison with 2016 (7.2-21.4 $\mathrm{m}^{3} \mathrm{ha}^{-1}$; Table 5). During 10 years, volume of dead wood increased by $127.2 \%$. Dead wood accounted for $3.9-13.2 \%$ of the total wood volume (live and dead trees). The share of lying dead wood prevailed slightly $(53.7 \%)$, while standing dead wood prevailed in 2016 (58.4\%). Moreover in 2006, dead wood of birch was not found. Nearly no changes occurred in the proportion of dead wood in the individual stages of decomposition.

\section{Structure, Dynamics and Game Damage of Natural Regeneration}

The number of individuals of natural regeneration ranged from 1,700 (PRP 5) to 10,250 (PRP 2) recruits ha ${ }^{-1}$ in 2006 (Table 6). In the course of 10 years, the PRPs 2-6 had seen an increase in the

Table 5. The volume of standing, lying and total dead wood differentiated by the degrees of decomposition on permanent research plots 1-6 in 2006 and 2016

\begin{tabular}{|c|c|c|c|c|c|c|c|c|c|c|c|c|c|}
\hline \multirow{3}{*}{ PRP } & \multirow{3}{*}{ Year } & \multicolumn{11}{|c|}{ Degrees of decomposition of dead wood $\left(\mathrm{m}^{3} \mathrm{ha}^{-1}\right)$} & \multirow{3}{*}{ Total } \\
\hline & & \multicolumn{5}{|c|}{ Standing dead wood } & \multicolumn{6}{|c|}{ Lying dead wood } & \\
\hline & & 1. & 2. & 3. & 4. & Total & 1. & 2. & 3. & 4. & 5. & Total & \\
\hline \multirow[t]{2}{*}{1} & 2006 & 2.4 & 5.2 & 2.3 & 0.0 & 9.9 & 0.0 & 0.3 & 1.0 & 0.0 & 0.0 & 1.3 & 11.2 \\
\hline & 2016 & 3.1 & 12.3 & 6.2 & 0.0 & 21.6 & 0.0 & 0.1 & 1.4 & 4.2 & 0.4 & 6.1 & 27.7 \\
\hline \multirow[t]{2}{*}{2} & 2006 & 0.5 & 2.3 & 3.5 & 0.1 & 6.4 & 0.0 & 0.4 & 0.4 & 0.0 & 0.0 & 0.8 & 7.2 \\
\hline & 2016 & 1.7 & 1.8 & 8.0 & 0.0 & 11.5 & 0.4 & 0.1 & 0.8 & 3.0 & 0.0 & 4.3 & 15.8 \\
\hline \multirow[t]{2}{*}{3} & 2006 & 0.2 & 2.8 & 2.2 & 0.1 & 5.3 & 0.0 & 2.1 & 1.4 & 0.7 & 0.0 & 4.2 & 9.5 \\
\hline & 2016 & 1.2 & 4.9 & 4.7 & 0.6 & 11.4 & 0.0 & 0.4 & 4.8 & 6.7 & 1.4 & 13.3 & 24.7 \\
\hline \multirow[t]{2}{*}{4} & 2006 & 6.3 & 9.0 & 0.0 & 0.0 & 15.3 & 0.1 & 1.4 & 3.7 & 0.9 & 0.0 & 6.1 & 21.4 \\
\hline & 2016 & 0.6 & 23.2 & 1.1 & 0.0 & 24.9 & 0.2 & 0.0 & 4.4 & 7.0 & 2.8 & 14.4 & 39.3 \\
\hline \multirow[t]{2}{*}{5} & 2006 & 2.4 & 2.9 & 0.0 & 0.0 & 5.3 & 0.7 & 3.1 & 1.3 & 0.0 & 0.0 & 5.1 & 10.4 \\
\hline & 2016 & 4.4 & 9.2 & 0.0 & 0.0 & 13.6 & 0.0 & 3.3 & 3.5 & 5.7 & 2.0 & 14.5 & 28.1 \\
\hline \multirow[t]{2}{*}{6} & 2006 & 0.5 & 6.2 & 1.4 & 0.1 & 8.2 & 0.2 & 0.5 & 2.8 & 0.6 & 0.0 & 4.1 & 12.3 \\
\hline & 2016 & 0.0 & 7.1 & 4.6 & 0.0 & 11.7 & 0.0 & 0.0 & 2.6 & 12.2 & 1.5 & 16.3 & 28.0 \\
\hline
\end{tabular}

Table 6. Number and share of natural regeneration and mean recruit height differentiated by tree species in 2006 and 2016

\begin{tabular}{|c|c|c|c|c|c|c|c|c|c|c|c|c|c|c|c|}
\hline \multirow{3}{*}{ PRP } & \multirow{3}{*}{ Year } & \multicolumn{9}{|c|}{ Density } & \multicolumn{5}{|c|}{ Mean height } \\
\hline & & \multicolumn{2}{|c|}{ Pinus } & \multicolumn{2}{|l|}{ Picea } & \multicolumn{2}{|c|}{ Betula } & \multicolumn{2}{|c|}{ Fagus } & \multirow{2}{*}{$\begin{array}{c}\text { Total } \\
\text { pcs ha }^{-1}\end{array}$} & \multirow{2}{*}{$\begin{array}{c}\text { Pinus } \\
\mathrm{cm} \\
\end{array}$} & \multirow{2}{*}{$\begin{array}{c}\text { Picea } \\
\mathrm{cm}\end{array}$} & \multirow{2}{*}{$\begin{array}{c}\text { Betula } \\
\mathrm{cm}\end{array}$} & \multirow{2}{*}{$\begin{array}{c}\text { Fagus } \\
\mathrm{cm}\end{array}$} & \multirow{2}{*}{$\begin{array}{c}\text { Mean } \\
\mathrm{cm}\end{array}$} \\
\hline & & pcs ha $^{-1}$ & $\%$ & pcs ha $^{-1}$ & $\%$ & pcs ha $^{-1}$ & $\%$ & pcs ha $^{-1}$ & $\%$ & & & & & & \\
\hline \multirow[t]{2}{*}{1} & 2006 & 8,250 & 94.2 & 250 & 2.9 & 250 & 2.9 & - & 0.0 & 8,750 & 137 & 14 & 6 & - & 129 \\
\hline & 2016 & 7,750 & 100.0 & - & 0.0 & - & 0.0 & - & 0.0 & 7,750 & 280 & - & - & - & 280 \\
\hline \multirow[t]{2}{*}{2} & 2006 & 9750 & 95.2 & 250 & 2.4 & 250 & 2.4 & - & 0.0 & 10,250 & 89 & 12 & 7 & - & 85 \\
\hline & 2016 & 11,500 & 97.9 & 250 & 2.1 & - & 0.0 & - & 0.0 & 11,750 & 255 & 57 & - & - & 250 \\
\hline \multirow[t]{2}{*}{3} & 2006 & 7,000 & 70.0 & 250 & 2.5 & 2,250 & 22.5 & 500 & 5.0 & 10,000 & 92 & 16 & 61 & 29 & 80 \\
\hline & 2016 & 9,750 & 56.5 & 500 & 2.9 & 6,500 & 37.7 & 500 & 2.9 & 17,250 & 147 & 53 & 122 & 82 & 132 \\
\hline \multirow[t]{2}{*}{4} & 2006 & 6,500 & 72.2 & - & 0.0 & 2,500 & 27.8 & - & 0.0 & 9,000 & 94 & - & 70 & - & 87 \\
\hline & 2016 & 9,500 & 66.7 & - & 0.0 & 4,750 & 33.3 & - & 0.0 & 14,250 & 153 & - & 142 & - & 149 \\
\hline \multirow[t]{2}{*}{5} & 2006 & 1,400 & 82.4 & 100 & 5.9 & 200 & 11.7 & - & 0.0 & 1,700 & 70 & 13 & 12 & - & 60 \\
\hline & 2016 & 3,900 & 100.0 & - & 0.0 & - & 0.0 & - & 0.0 & 3,900 & 95 & - & - & - & 95 \\
\hline \multirow[t]{2}{*}{6} & 2006 & 1,300 & 72.2 & 100 & 5.6 & 300 & 16.6 & 100 & 5.6 & 1,800 & 73 & 10 & 25 & 132 & 65 \\
\hline & 2016 & 2,800 & 93.3 & - & 0.0 & 100 & 3.3 & 100 & 3.3 & 3,000 & 109 & - & 105 & 240 & 113 \\
\hline
\end{tabular}



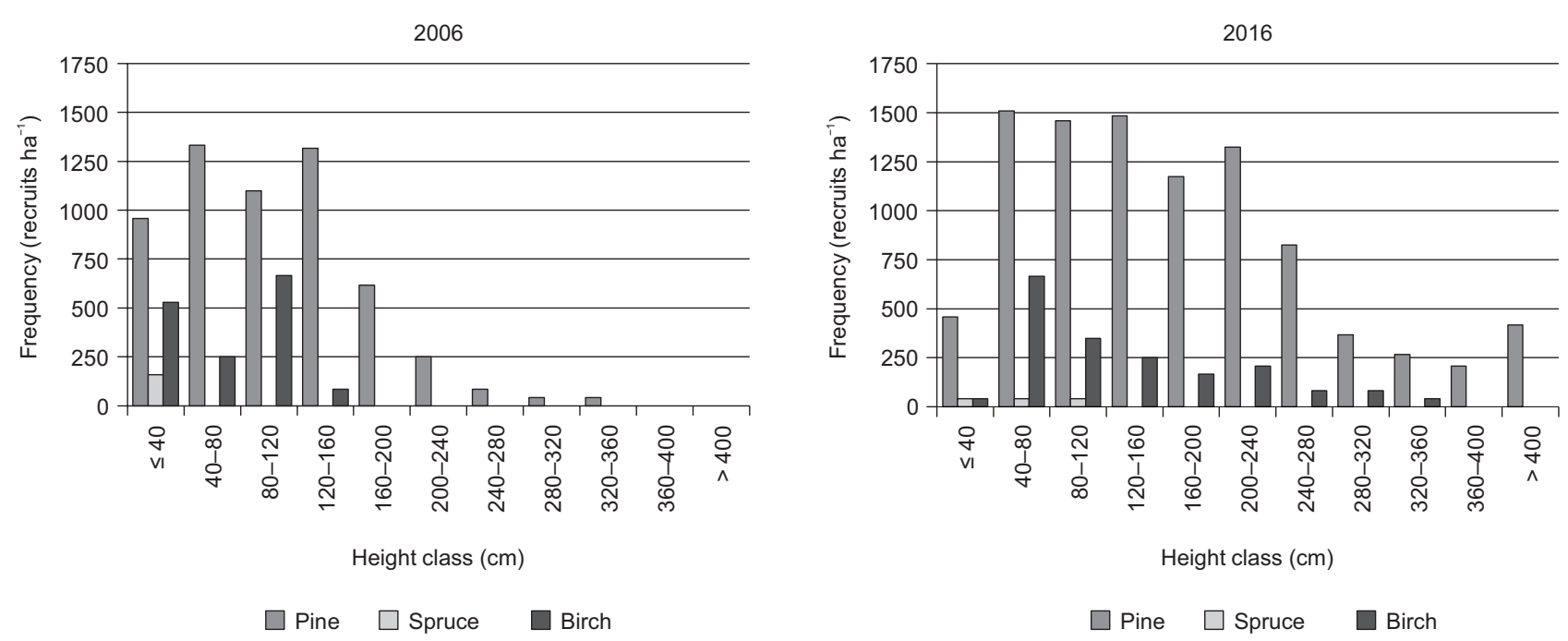

Fig. 8. The average height structure of natural regeneration on permanent research plots differentiated by tree species in 2006 and 2016

number of regeneration individuals, with only PRP 1 slightly decreasing. There occurred a significant shift towards the maturity of natural regeneration on all the PRPs (Fig. 8). In 2016, the number of natural regeneration ranged from 3,000 (PRP 6) to 17,250 (PRP 3) recruits ha ${ }^{-1}$ (Table 6). On average, pine represented $78.1 \%$, spruce $1.3 \%$, birch $19.6 \%$, and European beech (Fagus sylvatica L.) $1.0 \%$ of all regeneration individuals. The average height of the pine regeneration was $95-280 \mathrm{~cm}$, of spruce $53-57 \mathrm{~cm}$, of birch 105-142 cm and of beech 82-240 cm (Table 6).

In 2016, the share of individuals with the terminal shoot damaged by browsing was low (pine $1.6 \%$, spruce $8.7 \%$, birch $0.2 \%$ ), only in case of beech it was high $(36.2 \%)$. The most affected were individuals with a height of $20-80 \mathrm{~cm}$. Compared to 2016, the damage was significantly higher in 2006 (pine $12.2 \%$, spruce $19.4 \%$, birch $2.3 \%$, beech $92.5 \%$ ).

The species richness $D$ was medium on PRP 3 and low on remaining PRPs. The species heterogeneity

according to the $H^{\prime}$ entropy index was low on PRPs 1,2 and 5 and medium to high on PRPs 3, 4 and 6 . The species evenness of regeneration according to the index $E$ was low on PRPs 1, 2 and 5, medium to high on PRPs 3 and 6 low and very high on PRP 4. On PRPs 2 and 4, the situation was similar in 2016 and 2006. The decrease in biodiversity in the monitored years was observed on PRPs 1,5 and 6 , but it increased significantly only on PRPs 3 .

The spatial pattern of the regeneration was significantly aggregated on PRPs except PRP 2 and 4 according to monitored indices in 2016 (Table 7). The clustering of the regeneration individuals according to their distance (spacing) arises also from the Ripley $L$-function (Fig. 9). The distinctly clustered natural regeneration pattern was on PRPs 5 and 6, slightly clustered on PRP 3. On PRP 4, the horizontal structure of the regeneration was between the clustered and random spacing. On PRPs 1 and 2, a clustered regeneration was to the distance of $0.5 \mathrm{~m}$ and then

Table 7. Biodiversity indices of natural regeneration on permanent research plots 1-6 in 2006 and 2016

\begin{tabular}{|c|c|c|c|c|c|c|c|c|c|c|c|c|c|}
\hline PRP & Year & $\mathrm{D}$ & & $\mathrm{H}^{\prime}$ & & $E$ & & $\alpha^{*}$ & & $\mathrm{R}^{*}$ & & CSI* $^{*}$ & \\
\hline \multirow[t]{2}{*}{1} & 2006 & 0.220 & \multirow{2}{*}{$\searrow$} & 0.157 & \multirow{2}{*}{$\searrow$} & 0.143 & \multirow{2}{*}{$\searrow$} & 1.709 & \multirow{2}{*}{$\searrow$} & $0.898^{\mathrm{A}}$ & \multirow{2}{*}{$\nearrow$} & $0.565^{\mathrm{A}}$ & \multirow{2}{*}{$\searrow$} \\
\hline & 2016 & 0.000 & & 0.000 & & 0.000 & & 1.532 & & 0.912 & & 0.330 & \\
\hline \multirow[t]{2}{*}{2} & 2006 & 0.217 & \multirow{2}{*}{$\searrow$} & 0.138 & \multirow{2}{*}{$\searrow$} & 0.126 & \multirow{2}{*}{$\nearrow$} & $2.348^{\mathrm{A}}$ & \multirow{2}{*}{$\searrow$} & $0.822^{\mathrm{A}}$ & \multirow{2}{*}{$\nearrow$} & 0.306 & \multirow{2}{*}{$\searrow$} \\
\hline & 2016 & 0.107 & & 0.103 & & 0.149 & & 1.668 & & $0.868^{\mathrm{A}}$ & & 0.253 & \\
\hline \multirow[t]{2}{*}{3} & 2006 & 0.312 & \multirow{2}{*}{$\nearrow$} & 0.342 & \multirow{2}{*}{$\nearrow$} & 0.247 & \multirow{2}{*}{$\nearrow$} & $3.307^{\mathrm{A}}$ & \multirow{2}{*}{$\searrow$} & $0.748^{\mathrm{A}}$ & \multirow{2}{*}{$\pi$} & $0.509^{\mathrm{A}}$ & \multirow{2}{*}{$\searrow$} \\
\hline & 2016 & 0.326 & & 0.896 & & 0.646 & & $2.401^{\mathrm{A}}$ & & $0.780^{\mathrm{A}}$ & & $0.406^{\mathrm{A}}$ & \\
\hline \multirow[t]{2}{*}{4} & 2006 & 0.110 & \multirow{2}{*}{$\searrow$} & 0.591 & \multirow{2}{*}{$\nearrow$} & 0.852 & \multirow{2}{*}{$\nearrow$} & $2.703^{\mathrm{A}}$ & \multirow{2}{*}{$\nearrow$} & 0.911 & \multirow{2}{*}{$\nearrow$} & $0.409^{\mathrm{A}}$ & \multirow{2}{*}{$\searrow$} \\
\hline & 2016 & 0.109 & & 0.637 & & 0.918 & & $2.907^{\mathrm{A}}$ & & 0.933 & & 0.285 & \\
\hline \multirow[t]{2}{*}{5} & 2006 & 0.269 & \multirow{2}{*}{$\searrow$} & 0.327 & \multirow{2}{*}{$\searrow$} & 0.297 & \multirow{2}{*}{$\searrow$} & $4.056^{\mathrm{A}}$ & \multirow{2}{*}{$\searrow$} & $0.872^{\mathrm{A}}$ & \multirow{2}{*}{$\searrow$} & $0.961^{\mathrm{A}}$ & \multirow{2}{*}{$\searrow$} \\
\hline & 2016 & 0.000 & & 0.000 & & 0.000 & & $3.538^{\mathrm{A}}$ & & $0.871^{A}$ & & $0.818^{\mathrm{A}}$ & \\
\hline \multirow[t]{2}{*}{6} & 2006 & 0.271 & > & 0.429 & & 0.390 & & $2.664^{\mathrm{A}}$ & & $0.624^{\mathrm{A}}$ & & $0.844^{\mathrm{A}}$ & \\
\hline & 2016 & 0.250 & $\searrow$ & 0.291 & $\searrow$ & 0.265 & $\searrow$ & 1.762 & 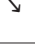 & $0.599^{\mathrm{A}}$ & $\searrow$ & $0.991^{\mathrm{A}}$ & r \\
\hline
\end{tabular}

Notes: D (Mai) - species richness, $\mathrm{H}^{\prime}$ (Shi) - species heterogeneity, E (Pii) - species evenness, $\alpha$ (P\&Mi) - index of non-randomness, R (C\&Ei) - aggregation index, CSI (D\&Mi) - index of cluster size

${ }^{*}$ statistically significant for horizontal structure ( ${ }^{\mathrm{A}}$ - aggregation, ${ }^{\mathrm{R}}-$ regularity); changes: $\searrow-$ decrease, $\nearrow-$ increase. 

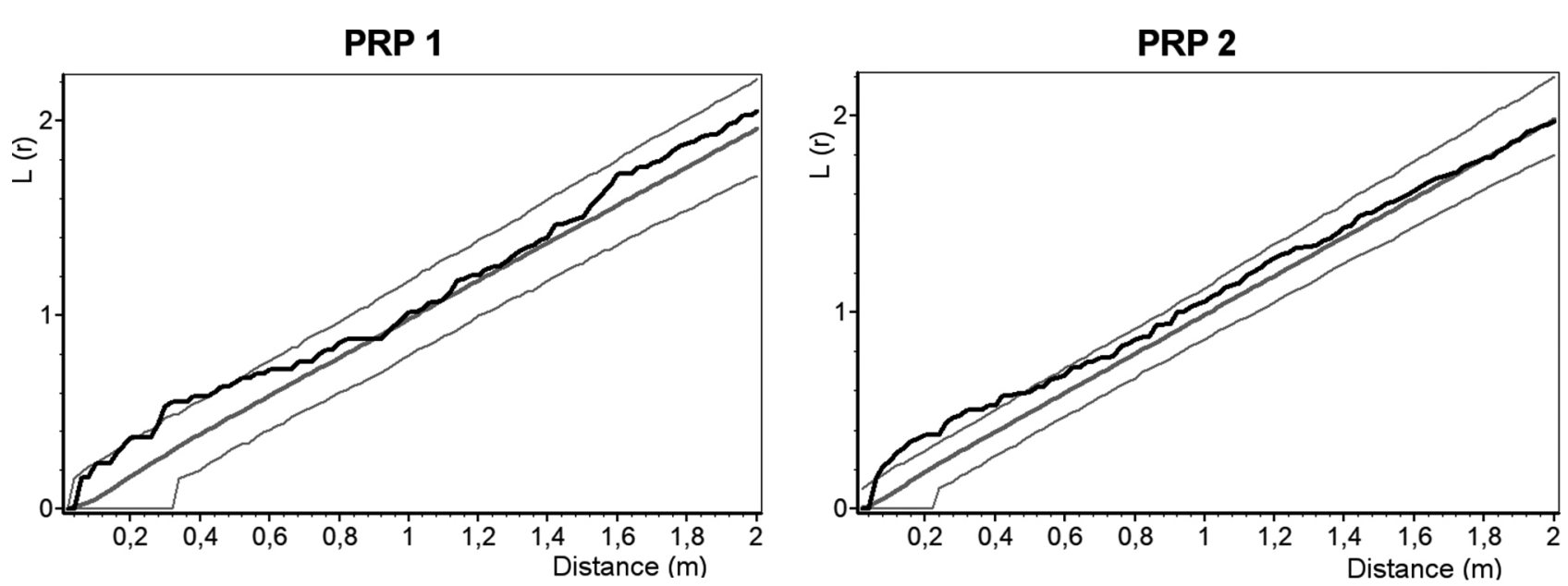

PRP 3

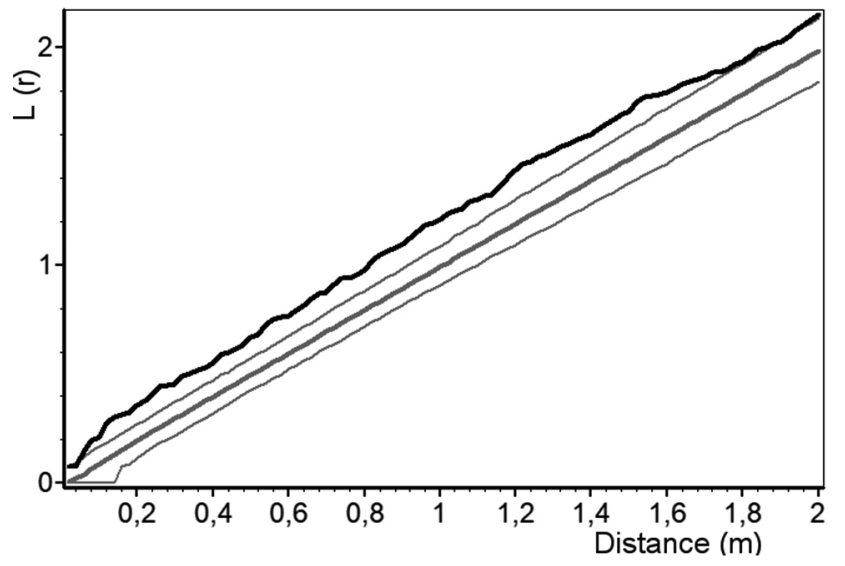

PRP 4

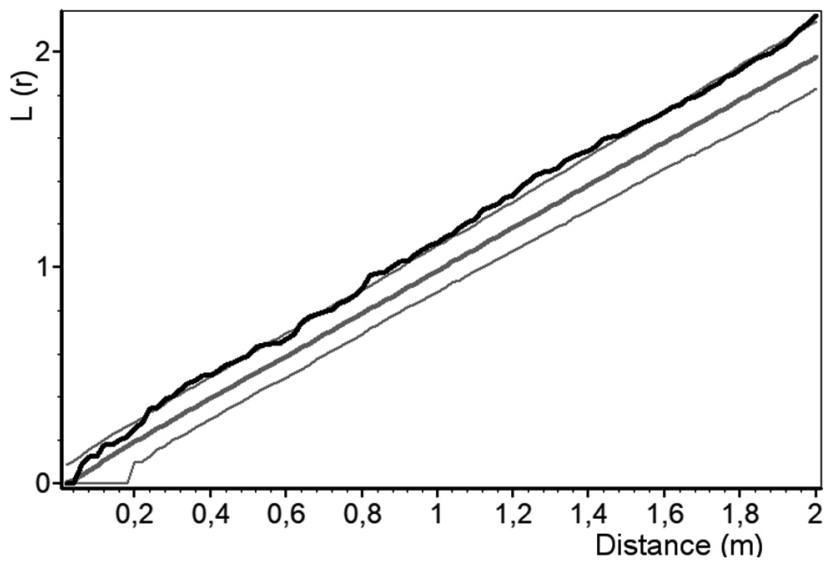

PRP 5

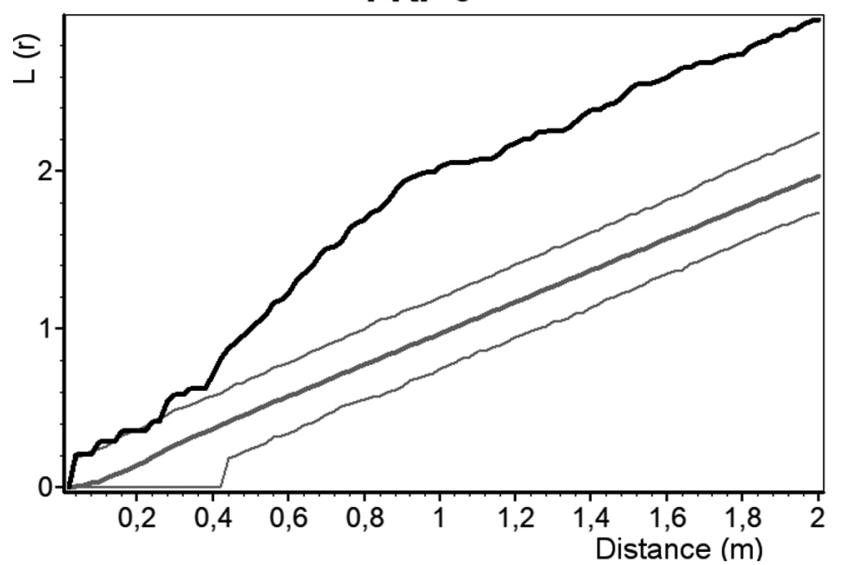

PRP 6

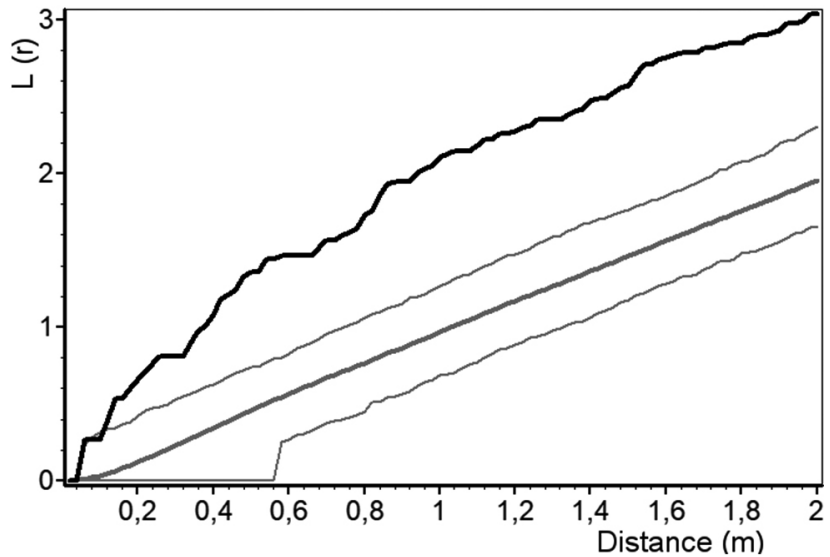

Fig. 9. The spatial pattern of natural regeneration on permanent research plots 1-6 expressed by $L$-function in 2016; the black line represents the $L$-function for real distances of recruits; the bold grey line represents the mean course for random spatial distribution and the two thinner central curves represent $95 \%$ interval of reliability; when the black line of recruits distribution on the plots is under (below) this interval, it indicates a tendency of recruits toward aggregation (regular) distribution

the distribution was random. In 2006 on the PRPs $1-6$, there was found clustered distribution of natural regeneration. During the monitored period, on PRPs horizontal structure was more aggregated in 2006 compared to 2016, only on PRP 4 distribution of recruits was more regular.

\section{Discussion}

As part of the ongoing climatic changes (Knoke et al., 2008; Bošela et al., 2016; Dyderski et al., 2018), and in the context of often borderline habitat conditions for the forest existence, natural pine 
ecosystems are rightfully receiving more and more attention (Popa et al., 2017; Wang et al., 2017). The structure and growth of pine stands in the Czech Republic were dealt with by Bílek et al. (2016); Vacek et al. (2016) or Sharma et al. (2017). The dynamics of relict pine stands in relation to environmental conditions were dealt with in the Czech Republic by Bílek et al. (2016) and Vacek et al. (2017).

The main characteristics of spontaneous development of natural pine stands in given conditions are high age of individual trees in the upper story, extraordinary regeneration capacity with predominantly clustered spatial distribution of seedlings and saplings, and a significant increase of dead wood during the monitoring period. The summary stand characteristics on PRPs such as tree density, basal area and growing stock have mostly increased over the monitored period and can be regarded as balanced. Generally, we assume that these structural attributes contribute to higher naturalness, heterogeneity and ecological stability of the studied stands, and thus can be considered as a possible mitigation measure to ongoing global climate change. Nevertheless, in the case of the studied areas, and also in comparison with other authors, the variability of the results is generally high. This is due to the interaction of numerous factors such as the growth characteristics of each species, climatic and edaphic habitat conditions, the structure of the stands and the previous management (Forrester, 2014; Bauhus et al., 2017).

According to Forrester et al. (2017), for example, mixed and unmixed stands can vary considerably in the productivity, function, and stability, the extent and direction of these differences being very heterogeneous. In the context of higher structural diversity, correlation with the production of above-ground biomass has been confirmed for the pine stands (Balvanera et al., 2006; Szwagrzyk \& Gazda, 2007; Ercanli \& Kahriman, 2015). The diameter structure on individual plots remained almost unchanged during the period under review and is markedly left-tailed with the Liocourt curve character. This arrangement is usually the result of the opening of the canopy cover when a relatively rapid onset of natural regeneration takes place (Franklin et al., 2002; Zeibig et al., 2005). The diameter structure in the shape of the Liocourt curve is also referred to as typical for the close to nature stands of other tree species (Král et al., 2010; Sagheb-Talebi et al., 2015). A similar left-tailed distribution as on our plots reported Szmyt and Tarasiuk (2018) from the pine forests in Poland. Their work shows clearly the increase in the thickness of the individuals on the research plots during the 14year period, which correlates with the decrease of their number.

For the natural regeneration and the tree layer, there is a predominant random to cluster spatial distribution, while the horizontal structure has changed only slightly with no prevailing trend. A cluster distribution is typical for areas with more extreme habitat conditions (Šerá et al., 2000; Bulušek et al., 2016) and also results from the establishment and growth of natural regeneration in gaps of the parent stand (Bolte et al., 2014). This is the preference of a micro-site with better light conditions. On the contrary, the mortality of individuals in the case of increasing stand density (Getzin et al., 2006; Das et al., 2011), or in the absence of openings in the stand (Haase et al., 1996; Uria-Diez \& Pommerening, 2017) contributes to the regularity of the spatial distribution. In connection with this, Szmyt \& Tarasiuk (2017) confirm the change in the stand structure during the stand development from random to regular. In the pine stands, a cluster arrangement (Brown et al., 2015; Tuten et al., 2015) and regular arrangement (Li et al., 2012) were confirmed according to various authors.

The tree ring analyses show that the age of the upper layer of the studied stands was in case of pine between 237-264 years. Precipitation had significantly higher effect on radial growth compared to temperature. Especially precipitation in June and July of the previous year and in May-July of the current year influenced radial growth positively. Similarly, the precipitation in May, June and July significantly positively influenced the radial growth of Scots pine trees in the Kuyavian-Pomerania region in Poland, while there was positive effect of the mean monthly temperature for February and March of the current year (Koprowski et al., 2012). Also study from Latvia showed, that the air temperature from the second half of January to the first half of April of the same year has significant effect on radial growth of pine (Zunde et al., 2008). In the relict pine stands in the national nature reserve (NNR) Adršpach-Teplice Rocks in the Czech Republic, the statistically important correlations of radial growth with the temperature in December of the previous year and in March and August of the current year were recorded. Similarly, significant positive correlations were found with the precipitation amount in July of the previous year and in June of the current year (Vacek et al., 2017). In natural lowlands in eastern Bohemia, radial growth was positively correlated with the temperature in March of the current year and precipitation in November and December of the previous year and February, March and April of the current year (Vacek et al., 2016). Also, other studies from the Mediterranean area (Augustaitis et al., 2007; Oberhuber et al., 2007; Bogino et al., 2009) suggest that drought is a decisive factor for the radial growth of Scots pine. Similarly, in the northeastern lowlands of Brandenburg (Germany), a sufficient amount of precipitation in the autumn of the previous year and summer 
precipitation of the current year are very important for foliage formation and radial growth. According to the work of Insinna et al. (2007), the temperature has less influence on growth processes than precipitation. From the regional standardized ring chronology, there is a relatively unstable radial growth between 1800-2017. Years with a low radial increase were in 1922, 1976, and 1998. Especially negative pointer year 1976 was the driest year since 1959 (annual precipitation $492 \mathrm{~mm}$, long-term average 620 $\mathrm{mm}$ ), the monthly rainfall in June reached only 22 $\mathrm{mm}$ (average $69 \mathrm{~mm}$ ) with high temperatures in the growing season $\left(1.2{ }^{\circ} \mathrm{C}\right.$ above the long-term average). Similarly, in 1998, when the very beginning of the growing season was marked by very high temperatures and minimal precipitation (April temperature $+2.1{ }^{\circ} \mathrm{C}$ and rainfall only $41 \%$ of the average).

In accordance with other studies (Vacek et al., 2017; Wilczyński, 2006), radial growth was negatively correlated with $\mathrm{SO}_{2}$ concentrations and ozone exposure. $\mathrm{NO}_{\mathrm{x}}$ concentrations had low effect on radial growth, while in other studies from natural pine stands in the Czech Republic mean $\mathrm{NO}_{\mathrm{x}}$ concentrations affected the radial growth positively (Vacek et al., 2016). On the other hand, high concentrations of $\mathrm{NO}_{x}$ and $\mathrm{SO}_{2}$ in combination with severe climate events can lead to serious defoliation (Vacek et al., 2016) with further degradation of the forest stands.

Dead wood as an important component of natural forest ecosystems (Ódor et al., 2006; Jakoby et al., 2010) occurred in the studied locality in 2016 in the range of $15.8-39.3 \mathrm{~m}^{3} \mathrm{ha}^{-1}$. During the research period, the volume of dead wood increased significantly (by $127.2 \%$ ) compared to $2006\left(7.2-21.4 \mathrm{~m}^{3}\right.$ $\left.\mathrm{ha}^{-1}\right)$. Within natural forest dynamics steep increase of dead wood volumes is mainly related to the degradation phase of the tree layer. Some authors also refer to spatial relationships and mutual competition of trees as important factors in relation to mortality (LeMay et al., 2009; Larson et al., 2015). Significantly higher volume of dead wood in pine primary forests in North America in the range of 37.2-124.1 $\mathrm{m}^{3}$ $\mathrm{ha}^{-1}$ are reported by Silver et al. (2013). Uotila et al. (2001) report in the pine primary forests in Finland and Russian Karelia $66.7 \mathrm{~m}^{3} \mathrm{ha}^{-1}$. On the contrary, similar results are presented from the relict pine forests of the NNR of the Adršpach-Teplice Rocks by Vacek et al. (2017) with an average dead wood stock of $33.1 \mathrm{~m}^{3} \mathrm{ha}^{-1}$. The standing and lying dead wood ratio on studied plots was consistent with the Karjalainen \& Kuuluvainen (2002), which presents a substantially identical standing (39\%) and lying dead wood $(61 \%)$ ratio.

Our results also show a significant regeneration capacity of researched pine stands. This is very important from the point of view of natural dynamics since natural regeneration is an important component of natural forest ecosystems (Petritan et al., 2007; Pardos et al., 2008; Dovčiak \& Brown, 2014). The number of natural regeneration individuals ranged from 3,000 to 17,250 recruits ha $^{-1}$. This density is substantially higher in comparison with another relict pine forest in Czech Republic, (Vacek et al., 2017). During the monitored period, a rather significant increase (by 55.0\%) in the number of natural regeneration was recorded, with the exception of one PRP, but Martín-Alcón et al. (2015) presents the opposite trend. The works by Štícha et al. (2010) and Prévosto et al. (2012) then present the competition of grass vegetation as a possible negative impact on natural regeneration. Other works present browsing as a negative effect for natural regeneration, especially for the attractive tree species (Ammer, 1996; Čermák et al., 2009). Even though in 2006 the game was damaging also other species, beech has to be judged as the most attractive tree species for ungulates in the studied locality.

\section{Conclusion}

During the monitored years 2006-2016, the changes in the diversity of the relict pine stands were generally low, while significant changes occurred in the development of natural regeneration. Under a reduced pressure of the ungulates, the development of the stand goes to greater spatial diversity and to a larger proportion of admixed trees such as birch, spruce, and beech. We conclude that natural stand dynamics characterised by gap formation and following regeneration process had positive effect on functional integrity of natural pine ecosystems. Under similar conditions, active management of forest stands should aim to achieve these attributes that are specific to natural pine stands. If passive management scenarios are preferred, control methods analysing the regeneration process and vitality of parent trees are needed. With respect to observed changes in the stand structure (success of natural regeneration and related increase in tree species diversity, balanced growing stock and dead wood, vertical and horizontal heterogeneity), spontaneous development on the stand level and in given temporal frame can be judged as suitable adaptation measure to ongoing climate change.

\section{Author Contributions}

S.V., Z.V. and J.R. planned and designed the experiment; Z.V., J.K, D.B. collected stand data, I.H. provided and processed meteorological data; Z.V. and J.K. analysed data; S.V., Z.V., J.B.. and L.B. interpreted the results and wrote the paper; all authors reviewed and edited the manuscript. 


\section{Acknowledgments}

This study was supported by the Ministry of Agriculture of the Czech Republic, Project No. QJ1520037 and by the Czech University of Life Sciences Prague, Faculty of Forestry and Wood Sciences, Internal Grant Agency, Project No. B03/18. We are also grateful to the Czech Hydrometeorological Institute in Prague for climatic data.

\section{Conflicts of Interest}

The authors declare no conflict of interest.

\section{References}

Allen CD, Savage M, Falk DA, Suckling KF, Swetnam TW, Schulke T, Stacey PB, Morgan P, Hoffman M \& Klingel JT (2002) Ecological restoration of southwestern ponderosa pine ecosystems: a broad perspective. Ecology Applications 12: 1418-1433.

Ammer CH (1996) Impact of ungulates on structure and dynamics of natural regeneration of mixed mountain forests in the Bavarian Alps. Forest Ecology and Management 88: 43-53.

AOPK (2014) Plán péče o prrírodní rezervaci Kostelecké bory na období 2014-2023. AOPK ČR, Správa CHKO Kokořínsko, Mělník.

Augustaitis A, Augustaitiene I \& Deltuvas R (2007) Scots pine (Pinus sylvestris L.) crown defoliation in relation to the acid deposition and meteorology in Lithuania. Water, Air \& Soil Pollution 182: 335-348.

Balvanera P, Pfisterer AB, Buchmann N, He J-S, Nakashizuka T, Raffaelli D \& Schmid B (2006) Quantifying the evidence for biodiversity effects on ecosystem functioning and services. Ecology Letters 9: 1146-1156.

Bauhus J, Forrester DI, Gardiner B, Jactel H, Vallejo R \& Pretzsch H (2017) Ecological stability of mixed-species forests: Mixed-species forests (ed. by H Pretzsch, DI Forrester \& J Bauhus) Ecology and Management. Springer-Verlag: Berlin Heidelberg, Germany, pp. 337-382.

Bílek L, Vacek S, Vacek Z, Remeš J, Král J, Bulušek D \& Gallo J (2016) How close to nature is close-tonature pine silviculture? Journal of Forest Science 62: 24-34.

Biondi F \& Waikul K (2004) Dendroclim 2002: $\mathrm{AC}++$ program for statistical calibration of climate signals in tree ring chronologies. Computers \& Geosciences 30: 303-311.

Bogino S, Fernández Nieto MJ \& Bravo F (2009) Climate effect on radial growth of Pinus sylvestris at its southern and western distribution limits. Silva Fennica 43: 609-623.
Bohn U, Neuhäusl R, von Gollub G \& Hettwer C (2003) Karte der natürlichen Vegetation Europas. Maßstab 1:2500000. Teil 3: Karten. Münster (Landwirtschaftsverlag).

Bolte A, Hilbrig L, Grundmann BM \& Roloff A (2014) Understory dynamics after disturbance accelerate succession from spruce to beech-dominated forest-the Siggaboda case study. Annals of Forest Science 71: 139-147.

Bošela M, Štefančík I, Petráš R \& Vacek S (2016) The effects of climate warming on the growth of European beech forests depend critically on thinning strategy and site productivity. Agriculture and Forest Meteorology 222: 21-31.

Brown PM, Battaglia MA, Fornwalt PJ, Gannon B, Huckaby LS, Julian C \& Cheng AS (2015) Historical (1860) forest structure in ponderosa pine forests of the northern Front Range, Colorado. Canadian Journal of Forest Research 45: 1462-1473.

Bulušek D, Vacek Z, Vacek S, Král J, Bílek L \& Králíček I (2016) Spatial pattern of relict beech (Fagus sylvatica L.) forests in the Sudetes of the Czech Republic and Poland. Journal of Forest Science 62: 293-305.

Burrascano S, Sabatini FM \& Blasi C (2011) Testing indicators of sustainable forest management on understorey composition and diversity in southern Italy through variation partitioning. Plant Ecology 212: 829-841.

Čermák P, Horsák P, Špiřík M \& Mrkva R (2009) Relationships between browsing damage and woody species dominance. Journal of Forest Science 55: 23-31.

Chytrý M, Kučera T, Koči M \& Grulich V \& Lustyk P (2010) Katalog biotopů České republiky. Agentura ochrany prírody a krajiny ČR, Praha.

Clark PJ \& Evans FC (1954) Distance to nearest neighbour as a measure of spatial relationship in populations. Ecology 35: 445-453.

Das A, Battles J \& Stephenson NL \& van Mantgem PJ (2011) The contribution of competition to tree mortality in old-growth coniferous forests. Forest Ecology and Management 261: 1203-1213.

David FN \& Moore PG (1954) Notes on contagious distributions in plant populations. Annals of Botany $18: 47-53$.

De Chantal M, Leinonen K, Kuuluvainen T \& Cescatti A (2003) Early response of Pinus sylvestris and Picea abies seedlings to an experimental canopy gap in a boreal spruce forest. Forest Ecology and Management 176: 321-336.

Déchêne AD \& Buddle CM (2010) Decomposing logs increase oribatid mite assemblage diversity in mixedwood boreal forest. Biodiversity and Conservation 19: 237-256.

Dehlin H, Nilsson MC, Wardle DA \& Shevtsova A (2004) Effects of shading and humus fertility on 
growth, competition, and ectomycorrhizal colonization of boreal forest tree seedlings. Canadian Journal of Forest Research 34: 2573-2586.

Dobrowolska D \& Veblen TT (2008) Treefall-gap structure and regeneration in mixed Abies alba stands in central Poland. Forest Ecology and Management 255: 3469-3476.

Dovčiak M \& Brown J (2014) Secondary edge effects in regenerating forest landscapes: vegetation and microclimate patterns and their implications for management and conservation. New Forests 45: 733-744.

Durak T \& Durak R (2015) Vegetation changes in meso-and eutrophic submontane oak-hornbeam forests under long-term high forest management. Forest Ecology and Management 354: 206-214.

Dyderski MK, Paź S, Frelich LE \& Jagodziński AM (2018) How much does climate change threaten European forest tree species distributions? Global Changing Biology 24: 1150-1163.

Ercanli I \& Kahriman A (2015) The evaluation of different forest structural indices to predict the stand aboveground biomass of even-aged Scotch pine (Pinus sylvestris L.) forests in Kunduz, Northern Turkey. Environmental Monitoring and Assessment 187: 90.

Forrester DI (2014) The spatial and temporal dynamics of species interactions in mixed-species forests: From pattern to process. Forest Ecology and Management 312: 282-292.

Forrester DI, Ammer C, Annighöfer PJ, Avdagic A, Barbeito I, Bielak K, Brazaitis G, Coll L, del Río M, Drössler L, Heym M, Hurt V, Löf M, Matović B, Meloni F, den Ouden J, Pach M, Pereira MG, Ponette Q, Pretzsch H, Skrzyszewski J, Stojanović D, Svoboda M, Ruiz-Peinado R, Vacchiano G, Verheyen K, Zlatanov T \& Bravo-Oviedo A (2017) Predicting the spatial and temporal dynamics of species interactions in Fagus sylvatica and Pinus sylvestris forests across Europe. Forest Ecology Management 405: 112-133.

Franklin JF, Spies TA, Pelt RV, Carey AB, Thornburgh DA, Berg, DR, Lindenmayer DB, Harmon ME, Keeton WS, Shaw DC, Bible K \& Chen J (2002) Disturbances and structural development of natural forest ecosystems with structural implications, using Douglas-fir forests as an example. Forest Ecology and Management 155: 399-423.

Füldner K (1995) Zur Strukturbeschreibung in Mischbeständen. Forstarchiv 66: 235-606.

Gaudio N, Balandier P, Perret S \& Ginisty C (2011) Growth of understorey Scots pine (Pinus sylvestris L.) saplings in response to light in mixed temperate forest. Forestry 84: 187-195.

Getzin S, Dean C, He F, Trofymow JA, Wiegand K \& Wiegand T (2006) Spatial patterns and competition of tree species in a Douglas-fir chron- osequence on Vancouver Island. Ecography 29: 671-682.

Griess VC, Acevedo R, Härtl F, Staupendahl K \& Knoke $T$ (2012) Does mixing tree species enhance stand resistance against natural hazards? A case study for spruce. Forest Ecology and Management 267: 284-296.

Grissino-Mayer HD, Holmes RL \& Fritts HC (1992) International tree-ring data bank program library: user's manual. Laboratory of Tree-Ring Research, University of Arizona, Tuscon, USA.

Haase P, Pugnaire FI, Clark SC \& Incoll LD (1996) Spatial patterns in a two-tiered semi-arid shrubland in southeastern Spain. Journal of Vegetation Science 7: 527-534.

Hlásny T, Barka I, Roessiger J, Kulla L, Trombik J, Sarvašová Z, Bucha T, Kovalčík M \& Čihák T (2017) Conversion of Norway spruce forests in the face of climate change: a case study in Central Europe. European Journal of Forest Research 136: 10131028.

Insinna P, Jalkanen R \& Götz B (2007) Climate impact on 100-year foliage chronologies of Scots pine and Ponderosa pine in the northeast lowlands of Brandenburg, Germany. Silva Fennica 41: 605-620.

Jaehne S \& Dohrenbusch A (1997) Ein Verfahren zur Beurteilung der Bestandesdiversität. Forstwissenschlaftliches Centralblat 116: 333-345.

Jakoby O, Rademacher Ch \& Grimm V (2010) Modelling dead wood islands in European beech forests: how much and how reliably would they provide dead wood? European Journal of Forest Research 129: 659-668.

Karjalainen L \& Kuuluvainen T (2002) Amount and diversity of coarse woody debris within a boreal forest landscape dominated by Pinus sylvestris in Vienansalo wilderness, eastern Fennoscandia. Silva Fennica 36: 147-167.

Kazda M \& Pichler M (1998) Priority assessment for conversion of Norway spruce forests through introduction of broadleaf species. Forest Ecology and Management 102: 245-258.

Knibbe B (2007) PAST 4: personal analysis system for tree ring research, Version 4.2. SCIEM, Vienna.

Knoke T, Ammer C, Stimm B \& Mosandl R (2008) Admixing broadleaved to coniferous tree species: a review on yield, ecological stability and economics. European Journal of Forest Research 127: 89-101.

Koprowski M, Przybylak R, Zielski A \& Pospieszyńska A (2012) Tree rings of Scots pine (Pinus sylvestris L.) as a source of information about past climate in northern Poland. International Journal of Biometeorology 56: 1-10. 
Král K, Vrška T, Hort L, Adam D \& Šamonil P (2010) Developmental phases in a temperate natural spruce-fir-beech forest: determination by a supervised classification method. European Journal of Forest Research 129: 339-351.

Kučera T (1999) Reliktní bory, sutové a roklinové lesy. AOPK, Praha, Czech Republic.

Lanier L, Badré M, Delabraze P, Dubourdieu J \& Flammarion JP (1986) Précis de sylviculture. ENGREF, Nancy, France.

Larson AJ, Lutz JA, Donato DC, Freund JA, Swanson ME, HilleRisLambers J, Sprugel DF \& Franklin JF (2015) Spatial aspects of tree mortality strongly differ between young and old-growth. Ecology 96: 2855-2861.

LeMay V, Pommerening A \& Marshall P (2009) Spatio-temporal structure of multi-storied, multi-aged interior Douglas fir (Pseudotsuga menziesii var. glauca) stands. Journal of Ecology 97: 10621074.

Li Y, Hui G, Zhao Z \& Hu Y (2012) The bivariate distribution characteristics of spatial structure in natural Korean pine broad-leaved forest. Journal of Vegetation Science 23: 1180-1190.

Lilja S \& Kuuluvainen T (2005) Structure of old Pinus sylvestris dominated forest stands along a geographic and human impact gradient in mid-boreal Fennoscandia. Silva Fennica 39: 407-428.

Maltamo M, Packalen P, Yu X, Eerikainen K, Hyyppa J \& Pitkanen J (2005) Identifying and quantifying structural characteristics of heterogeneous boreal forests using laser scanner data. Forest Ecology and Management 216: 41-50.

Margalef R (1958) Information theory in ecology. General Systems 3: 36-71.

Martín-Alcón S, Coll L \& Salekin S (2015) Stand-level drivers of tree-species diversification in Mediterranean pine forests after abandonment of traditional practices. Forest Ecology and Management 353: 107-117.

Matuszkiewicz JM, Kowalska A, Kozłowska A, Roo-Zielińska E \& Solon J (2013) Differences in plant-species composition, richness and community structure in ancient and post-agricultural pine forests in central Poland. Forest Ecology and Management 310: 567-576.

Medail F (2001) Biogéographie, écologie et valeur patrimoniale des forêts de pin sylvestre (Pinus sylvestris $\mathrm{L}$.) en région méditerranéenne. Forêt Méditerrannéenne 22: 5-22.

Mikeska M \& Vacek S (2008) Typologické vymezení, struktura a management prrirozených borů a borových doubrav v CR. Lesnická práce, s. r. o.: Kostelec nad Černými lesy, Czech Republic.

Mirschel F, Zerbe S \& Jansen F (2011) Driving factors for natural tree rejuvenation in anthropogen- ic pine (Pinus sylvestris L.) forests of NE Germany. Forest Ecology and Management 261: 683-694.

Mountford MD (1961) On E. C. Pielou s index of nonrandomness. Journal of Ecology 49: 271-275.

Neuner S, Albrecht A, Cullmann D, Engels F, Griess VC, Hahn WA, Hanewinkel M, Härtl F, Kölling C, Staupendahl K \& Knoke T (2014) Survival of Norway spruce remains higher in mixed stands under a dryer and warmer climate. Global Changing Biology 21: 935-946.

Oberhuber W, Stumböck W \& Kofler W (1998) Climate-tree-growth relationships of Scots pine stands (Pinus sylvestris L.) exposed to soil dryness. Trees 13: 19-27.

Ostonen I, Lohmus K, Helmisaari HS, Truu J \& Meel $S$ (2007) Fine root morphological adaptations in Scots pine, Norway spruce and silver birch along a latitudinal gradient in boreal forests. Tree Physiology 27: 1627-1634.

Ódor P, Heilmann-Clausen J, Christensen M, Aude E, van Dort KW, Piltaver A, Siller I, Veerkamp MT, Walleyn R, Standovar T, van Hees AFM, Kosec J, Matocec N, Kraigher H \& Grebenc T (2006) Diversity of dead wood inhabiting fungi and bryophytes in semi-natural beech forests in Europe. Biological Conservation 131: 58-71.

Pardos M, Montes F \& Cañellas I (2008) Spatial dynamics of natural regeneration in two differently managed Pinus sylvestris stands before and after silvacultural intervention using replicated spatial point patterns. Forest Science 54: 260-272.

Passarge H (1963) Zur soziologischen Gliederung von Kiefernwäldern im nordöstlichen Mitteleuropa. Archiv für Forstwesen 12: 1159-1176.

Peřina V (1960) Přeměny borových monokultur na pleistocenních terasách. SZN, Praha, Czech Republic.

Petritan AM, Von Lüpke B \& Petritan IC (2007) Effects of shade on growth and mortality of maple (Acer pseudoplatanus), ash (Fraxinus excelsior) and beech (Fagus sylvatica) saplings. Forestry 80: $397-$ 412.

Petritan IC, Marzano R, Petritan A \& Lingua E (2014) Overstory succession in a mixed Quercus petraeaFagus sylvatica old growth forest revealed through the spatial pattern of competition and mortality. Forest Ecology and Management 326: 9-17.

Pham AT, de Grandpré L, Gauthier S \& Bergeron Y (2004) Gap dynamics and replacement patterns in gaps of the northeastern boreal forest of Quebec. Canadian Journal of Forest Research 34: 353-364.

Picon-Cochard C, Coll L \& Balandier P (2006) The role of below-ground competition during early stages of secondary succession: the case of 3-yearold Scots pine (Pinus sylvestris L.) seedlings in an abandoned grassland. Oecologia 148: 373-383. 
Pielou EC (1959) The use of point-to-plant distances in the study of the pattern of plant populations. Journal of Ecology 47: 607-613.

Poage NJ \& Tappeiner JC (2005) Tree species and size structure of old-growth Douglas-fir forests in central western Oregon, USA. Forest Ecology and Management 204: 329-343.

Popa I, Nechita C \& Hofgaard A (2017) Stand structure, recruitment and growth dynamics in mixed subalpine spruce and Swiss stone pine forests in the Eastern Carpathians. Science of the Total Environment 598: 1050-1057.

Prévosto B, Amandier L, Quesney T, de Boisgelin G \& Ripert C (2012) Regenerating mature Aleppo pine stands in fire-free conditions: site preparation treatments matter. Forest Ecology and Management 282: 70-77.

Puettmann KJ, Wilson SM, Baker SC, Donoso PJ, Drössler L, Amente G, Harvey BD, Knoke T, Lu Y, Nocentini S, Putz FE, Yoshida T \& Bauhus J (2015) Silvicultural alternatives to conventional even-aged forest management - what limits global adoption? Forest Ecosystems 2: 8.

Quitt E (1971) Klimatické oblasti Československa. Studia Geographica 16. Geografický ústav ČSAV, Brno, Czech Republic.

Radzka E \& Rymuza K (2015) Multi-trait analysis of agroclimate variations during the growing season in east-central Poland (1971-2005). International Agrophysics 29: 213-219.

Reich PB (2014) The world-wide 'fast-slow' plant economics spectrum: a traits manifesto. Journal of Ecology 102: 275-301.

Reynolds RT, Sanchez Meador AJ, Youtz JA, Nicolet T, Matonis MS, Jackson PL, DeLorenzo DG \& Graves AD (2013) Restoring composition and structure in Southwestern frequent-fire forests: A science-based framework for improving ecosystem resiliency. USDA Forest: Service, Rocky Mountain Research Station, Fort Collins, Colorado, USA, General Technical Report RMRS-GTR-310.

Richardson DM (2000) Ecology and biogeography of Pinus. Cambridge University Press, Cambridge, UK.

Rouvinen S \& Kuuluvainen T (2005) Tree diameter distributions in natural and managed old Pinus sylvestris - dominated forests. Forest Ecology and Management 208: 45-61.

Sagheb-Talebi K, Delfan Abazari B \& Namiranian M (2005) Regeneration process in natural uneven-aged Caspian beech forests of Iran. Schweizerische Zeitschrift für Forstwesen 156: 477-480.

Salamon JA, Zaitsev A, Gärtner S \& Wolters V (2008) Soil macrofaunal response to forest conversion from pure coniferous stands into semi-natural montane forests. Applied Soil Ecology 40: 491498.
Sanchez-Gomez D, Zavala MA \& Valladares F (2006) Seedling survival responses to irradiance are differentially influenced by low-water availability in four tree species of the Iberian cool temperate Mediterranean ecotone. Acta Oecologica 30: 322-332.

Schou E, Jacobsen JB \& Kristensen KL (2012) An economic evaluation of strategies for transforming even-aged into near-natural forestry in a conifer-dominated forest in Denmark. Forest Policy and Economics 20: 89-98.

Schweingruber FH, Eckstein D, Serre-Bachet F \& Bräker OU (1990) Identification, presentation and interpretation of event years and pointer years in dendrochronology. Dendrochronologia 8: 9-38.

Šerá B, Falta V, Cudlín P \& Chmelíková E (2000) Contribution to knowledge of natural growth and development of mountain Norway spruce seedlings. Ekologia 19: 420-434.

Shannon CE (1948) A mathematical theory of communications. Bell System Technical Journal 27: 379-423.

Sharma RP, Bílek L, Vacek Z \& Vacek S (2017) Modelling crown width-diameter relationship for Scots pine in the Central Europe. Trees 31: 1875-1889.

Silver EJ, D'Amato AW, Fraver S, Palik BJ \& Bradford JB (2013) Structure and development of oldgrowth, unmanaged second-growth, and extended rotation Pinus resinosa forests in Minnesota, USA. Forest Ecology and Management 291: 110-118.

Šmilauer P \& Lepš J (2014) Multivariate analysis of ecological data using CANOCO 5. Cambridge University Press.

Spetich AM, Liechty HO, Stanturf JA, Marion DA, Luckow K, Meier CE \& Guldin JM (2001) Coarse woody debris of a prerestoration shortleaf pinebluestem forest: Proceedings of the eleventh biennial southern silvicultural research conference, Knoxville, Tennessee, NC: U.S. 22-22. March, (ed. by KW Outcalt) Department of Agriculture, Forest Service, Southern Research Station, Asheville, pp. 615-619.

Spies TA \& Franklin JF (1991) The structure of natural young, mature, and oldgrowth Douglas-fir forests in Oregon and Washington: Wildlife and vegetation of unmanaged Douglas-fir forests (ed. by LF Ruggerio, KB Aubry, AB Carey, MH Huff) USDA Forest Service General Technical Report: PNW-285. Pacific Northwest Research Station, Portland, pp. 90-109.

Sterck FJ, Martínez-Vilalta J, Mencuccini M, Cochard H, Gerrits P, Zweifel R, Herrero A, Korhonen JFJ, Llorens P, Nikinmaa E, Nolè A, Poyatos R, Ripullone F \& Sass Klaassen U (2012) Understanding trait interactions and their impacts on growth in Scots pine branches across Europe. Function Ecology 26: 541-549. 
Štícha V, Kupka I, Zahradník D \& Vacek S (2010) Influence of micro-relief and weed competition on natural regeneration of mountain forests in the Šumava Mountains. Journal of Forest Science 56: 218-224.

Szmyt J \& Tarasiuk S (2018) Species-specific spatial structure, species coexistence and mortality pattern in natural, uneven-aged Scots pine (Pinus sylvestris L.)-dominated forest. European Journal of Forest Research 137: 1-16.

Szwagrzyk J \& Gazda A (2007) Above-ground standing biomass and tree species diversity in natural stands of Central Europe. Journal of Vegetation Science 18: 555-562.

Tolasz R (2007) Atlas podnebí Česka. Český hydrometeorologický ústav, Praha.

Tuten MC, Meador AS \& Fu Fulé PZ (2015) Ecological restoration and fine-scale forest structure regulativ in southwestern ponderosa pine forests. Forest Ecology and Management 348: 57-67.

Uotila A, Maltamo M, Uuttera J \& Isomäki A (2001) Stand structure in semi-natural and managed forests in eastern Finland and Russian Karelia. Ecological Bulletins 49: 149-158.

Uria-Diez J \& Pommerening A (2017) Crown plasticity in Scots pine (Pinus sylvestris L.) as a strategy of adaptation to competition and environmental factors. Ecological Modelling 356: 117-126.

Vacek S, Moucha P, Bílek L, Mikeska M, Remeš J, Simon J, Hynek V, Šrůtka P, Schwarz O, Mánek J, Baláš M, Dort M, Podrázský V, Hejcman M, Hejcmanová P, Málková J, Stonawski J, Bednařík J, Vacek Z, Malík K, Štícha V \& Bulušek D (2012) Péče o lesní ekosystémy v chráněných územích ČR. Ministerstvo životního prostředí: 1st ed. Praha.

Vacek S, Vacek Z, Bílek L, Simon J, Remeš J, Hůnová I, Král J, Putalová T \& Mikeska M (2016) Structure, regeneration and growth of Scots pine (Pinus sylvestris L.) stands with respect to changing climate and environmental pollution. Silva Fennica 50: 1564.

Vacek S, Vacek Z, Remeš J, Bílek L, Hůnová I, Bulušek D, Putalová T, Král J \& Simon J (2017) Sensitivity of unmanaged relict pine forest in the Czech Republic to climate change and air pollution. Trees 31: 1599-1617.
Wang H, Wan P, Wang Q, Liu L, Zhang G \& Hui G (2017) Prevalence of inter-tree competition and its role in shaping the community structure of a natural Mongolian Scots pine (Pinus sylvestris var. mongolica) forest. Forests 8: 84.

Wilczyński S (2006) The variation of tree-ring widths of Scots pine (Pinus sylvestris L.) affected by air pollution. European Journal of Forest Research 125: 213-219.

Yamaguchi DK (1991) A simple method for cross-dating increment cores from living trees. Canadian Journal of Forest Research 21: 414-416.

Zadworny M, McCormack ML, Mucha J, Reich PB \& Oleksyn J (2016) Scots pine fine roots adjust along a 2000-km latitudinal climatic gradient. New Phytologist 212: 389-399.

Zadworny M, McCormack ML, Żytkowiak R, Karolewski P, Mucha J \& Oleksyn J (2017) Patterns of structural and defense investments in fine roots of Scots pine (Pinus sylvestris L.) across a strong temperature and latitudinal gradient in Europe. Global Change Biology 23: 1218-1231.

Zaitsev AS, Chauvat M \& Wolters V (2014) Spruce forest conversion to a mixed beech-coniferous stand modifies oribatid community structure. Applied Soil Ecology 76: 60-67.

Zeibig A, Diaci J \& Wagner S (2005) Gap disturbance patterns of a Fagus sylvatica virgin forest remnant in the mountain vegetation belt of Slovenia. Forest Snow and Landscape Research 79: 69-80.

Zerbe S \& Brande A (2003) Woodland degradation and regeneration in Central Europe during the last 1000 years, a case study in NE Germany. Phytocoenologia 33: 683-700.

Zerbe S (2002) Restoration of natural broad-leaved woodland in Central Europe on sites with coniferous forest plantations. Forest Ecology and Management 167: 27-42.

Zunde M, Briede A \& Elferts D (2008) Influence of climatic factors on the annual radial growth of Scots pine (Pinus sylvestris L.) in Western Latvia. Proceedings of the Latvian Academy of Sciences. Section B. Natural, Exact, and Applied Sciences 62: $120-128$. 